\title{
Agents and Approaches for Lytic Induction Therapy of Epstein-Barr Virus Associated Malignancies
}

\author{
Zlata Novalić\#, Tess M van Rossen\#, Astrid E Greijer and Jaap M Middeldorp* \\ Department of Pathology, VU University Medical Center, 1081 HV Amsterdam, The Netherlands \\ \#Contributed equally
}

\begin{abstract}
Epstein-Barr virus (EBV) is causally associated with multiple cancers of epithelial and lymphoid origin. Generally, EBV establishes a lifelong quiescent homeostasis (latency) exerting its immune modulating and oncogenic properties only under certain conditions. Lytic replicative EBV infection is restricted to differentiated oropharyngeal epithelia and plasma B-cells. In EBV-associated tumor cells viral gene expression is limited to defined latency programs, without overt virus "lytic" replication. Artificial triggering of EBV lytic replication with chemical agents (drugs) forms the basis of cytolytic virus activation (CLVA) therapy currently under clinical investigation for treating EBV-positive malignancies. Reactivation from latency requires expression of viral transactivator proteins BZLF1 (Zta) and BRLF1 (Rta). In tumor cells, the BZLF1 promoter (Zp) is highly methylated and generally inactive. However, $\mathrm{Zp}$ can be triggered into a self-enhancing activation loop in response to chemical or biological agents, including cytostatic drugs and epigenetic modifiers. This process is orchestrated by Zp-binding cellular transcription factors, such as myocyte enhancer factor 2 (MEF2), specificity protein 1 (SP1), and zinc finger E-box binding homeobox (ZEB) proteins. Understanding the mechanism of lytic induction by chemical inducers is essential for developing effective therapies. This review provide a short overview of EBV biology and will focus on branded and novel agents (drugs) used for EBV lytic induction and discuss molecular mechanisms by which the EBV lytic switch is triggered and controlled.
\end{abstract}

Keywords: Epstein-Barr virus; Malignancies; Lytic induction; Nasopharyngeal carcinoma

\section{Introduction}

Epstein Barr virus (EBV) is a gamma herpes virus that is ubiquitous in humans, infecting more than $90 \%$ of the world population [1]. The most common disease manifestation is infectious mononucleosis (IM), also known as glandular fever or kissing disease, a self-limiting inflammatory illness associating with primary infection. Importantly, besides it's link with several chronic and autoimmune diseases which will not to be discussed here, EBV is associated with a variety of epithelial and lymphoid malignancies, including undifferentiated nasopharyngeal carcinoma (NPC), 10\% of all gastric carcinomas (GC) worldwide, endemic Burkitt lymphoma (BL), 50-90\% of classic Hodgkin's Disease, various T-/NK-/B-cell non-Hodgkin lymphoma's and B-cell lymphoma's in immune suppressed individuals [1]. The virus exists in the host in either a reproductive lytic or a quiescent latent state. During primary infection, EBV infects and transforms naive $B$ cells into rapidly growing $B$-cell blasts, which are effectively eliminated by strong anti-EBV T-cell immune responses [2-4]. This strong early-stage $\mathrm{T}$-cell response, comprising both CD4+ and CD8+ $\mathrm{T}$-cells, is directed against viral peptide epitopes particularly of the lytic proteins of EBV $[4,5]$. The associating cytokine storm causes the symptoms characteristic of IM $[2,4,5]$.

Following primary infection, a lifelong dynamic balance is maintained between sporadic proliferation of virus-immortalized $\mathrm{B}$ cells and the controlling cytotoxic $\mathrm{T}$ cell response, which is highly effective in eliminating proliferating EBV transformed B-blasts $[4,5]$. In EBV positive cancers viral gene expression is limited to only a few latency-associated gene products which actively contribute to tumor cell growth, apoptosis resistance and immune escape $[1,6]$.

\section{EBV Life Cycles}

EBV persists for life in a low number metabolically quiescent memory-B-cells as a methylated and transcriptionally silenced nuclear dsDNA episome of 184 kilobases, expressing only non-coding small and microRNAs and being invisible to immune responses (Latency-0, also named true latency; Figure 1, left side) $[1,6]$. Dividing memory-Bcells may express a single EBV encoded protein, EBNA1, essential for maintenance of the latent viral genome in dividing cells (Latency-I). Some EBV+ B-cells may proliferate upon passage through lymphoid tissues, expressing two additional latent membrane proteins LMP1 and LMP2, which are barely immunogenic (Latency-II or Default Program). The full expression of EBV latent genes (Latency-III) is only seen during primary infection of B-cells, and sporadically in immunosuppressed individuals. Occasionally, antigenic triggering of an EBV carrying memory B-cell into antibody-producing plasma cell will reactivate the virus from latency into lytic reproduction (Figure 1, right side), a process that mainly occurs at oro-nasopharyngeal lymphoid tissues such as the tonsils, which are considered the homing site of most EBV carrying B-cells [6]. Virus from B-cells may transfer into submucosal epithelial cells [7-9], leading to abundant virus production and shedding [10]. Although EBV epithelial latency has been demonstrated in primary tonsil explant cultures [11], direct evidence of EBV latency in normal epithelia is rare [12]. In immunocompromised individuals, a lytic infection can persist manifesting as oral hairy leukoplakia (OHL) and uncontrolled proliferation of latent EBV-infected B cells can lead to the development of malignant lymphoma, illustrating the importance of immune control over both arms of the viral life cycle [13].

Besides infecting B cells and causing lymphoproliferative disorders,

*Corresponding author: Middeldorp JM, Department of Pathology, VU University Medical Center, De Boelelaan 1117, 1081 HV Amsterdam, The Netherlands, Tel: +0204442168; E-mail: j.middeldorp@vumc.nl

Received June 16, 2016; Accepted July 02, 2016; Published July 05, 2016

Citation: Novalić Z, van Rossen TM, Greijer AE, Middeldorp JM (2016) Agents and Approaches for Lytic Induction Therapy of Epstein-Barr Virus Associated Malignancies. Med chem (Los Angeles) 6: 449-466. doi:10.4172/21610444.1000384

Copyright: $\odot 2016$ Novalić Z, et al. This is an open-access article distributed under the terms of the Creative Commons Attribution License, which permits unrestricted use, distribution, and reproduction in any medium, provided the original author and source are credited. 


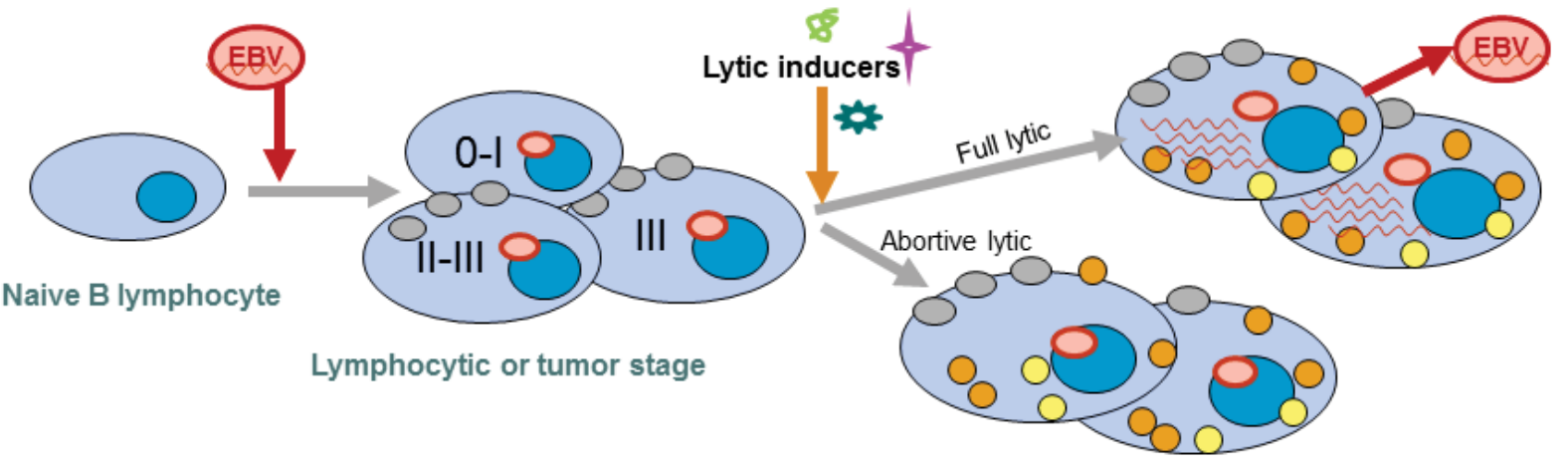

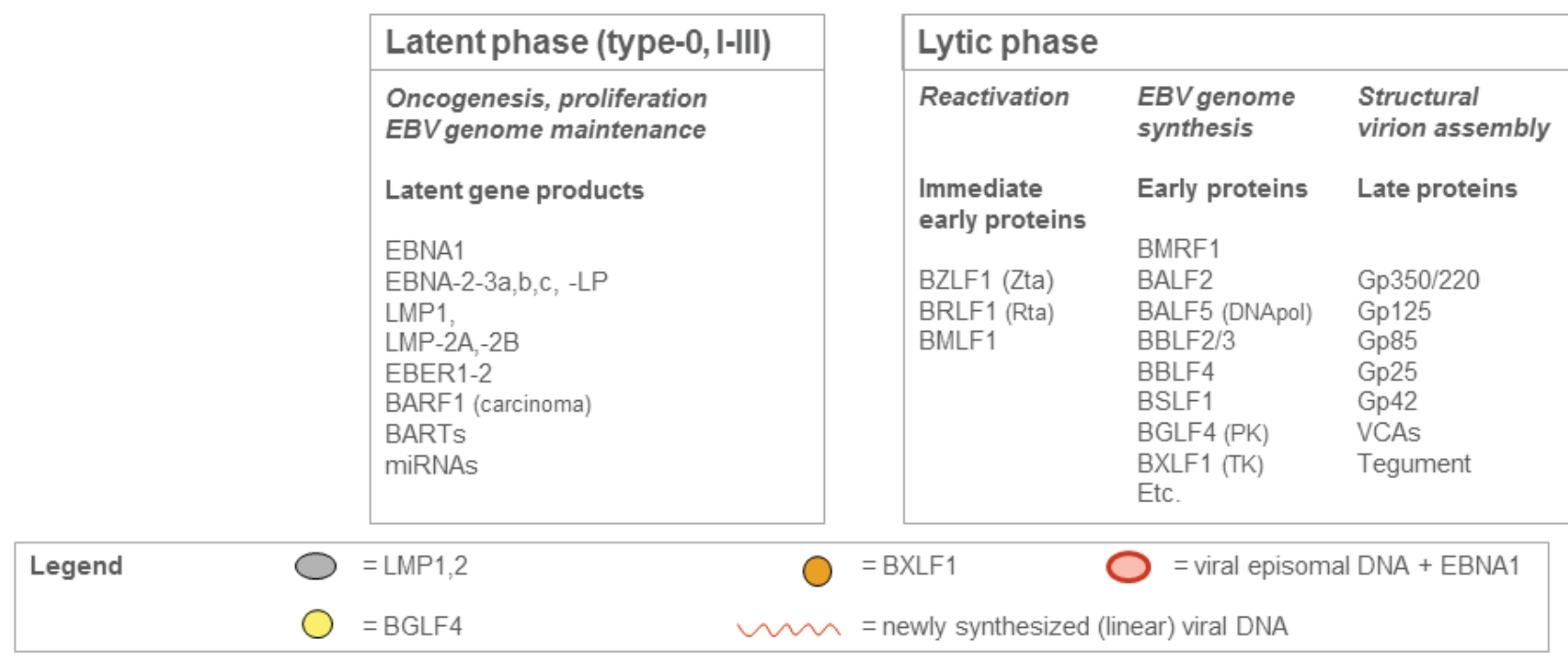

Latency-0 only in quiescent memory B-cells; latency-I, II, III expressed in proliferating (tumor) cells; see text)

Figure 1: Schematic overview of viral genes expressed in EBV latent and lytic phase.

EBV has the ability to infect epithelial cells by cell-to-cell contact which can lead to epithelial malignancies such as NPC and GC, where all cells harbour the virus, making it a valuable target for therapy [14]. The majority of tumour cells contain the virus in its latent form, producing only a few proteins necessary for EBV genome maintenance and tumour growth [15]. These latent proteins are low in immunogenicity and therefore difficult to be recognized by the immune system. This allows EBV-carrying tumour cells to successfully evade the host immune system.

\section{EBV Latency Gene Products and Functions}

The roles of EBV latent genes are summarized in recent reviews [15-17]. Via EBNA-1, the circular viral DNA episome is directly bound to host chromosomes ensuring reliable duplication by host DNA polymerases and enabling maintenance of viral genome in dividing cells. EBNA-1, EBNA-LPs, EBNA-2, EBNA-3A, EBNA-3C and LMP1 are individually essential for in vitro transformation of primary $B$ cells to lymphoblastoid cell lines $[1,6,16,17]$. The "higher EBNAs" (i.e., all EBNAs besides EBNA1) are involved in initial B-cell immortalization, but otherwise not expressed in human malignancies, with exception of lymphoproliferative diseases in severely immunosuppressed patients.

The key EBV oncogene, LMP1, is interacting with several host adapter proteins triggering multiple cellular signaling pathways such as NF-kB, JNK, p38 and JAK/STAT, P53/ATM. This is mediated by at least three distinct signal activating domains in $\mathrm{C}$-terminal sequence of LMP1 (CTAR1-3) [18]. For example, in B-cells LMP1 is mimicking T-cell stimulatory signaling by CD 40 mediated NF-kB activation and signal transduction pathway through interaction with TNFRassociated factors (TRAF's), especially TRAF1 and TRAF3 and TNFRassociated death domain protein (TRADD), preventing apoptosis and enhancing cell growth and oncogenic transformation [18-20]. The activated NF- $\mathrm{kB}$ translocates from cytoplasm to the nucleus and regulates target genes essential for cell proliferation and apoptosis resistance. When Janus kinase 3 (JAK3) binds to C-terminal domain of LMP1, it activates signal transducer activator of transcription (STAT) to upregulate transcription [21]. Furthermore, LMP1 activates the PI3-K /Akt pathway resulting enhanced cell survival and remodeling actin filament [22]. Importantly, LMP1 induces selective host DNA methylation, thereby limiting the expression of tumor suppressor genes and pro-apoptotic signaling and modulating "danger signaling" in general [23]. In order to limit oncogenic signaling, LMP1 rapidly associates with CD63 to be incorporated into intraluminal vesicles, where LMP1 loses its signaling capacity and is prepared for secretion in exosomes [24]. LMP2A mimics antigen-independent B-cell receptor (BCR) signaling by constitutive binding of Syk/Lyn and activation of the ERK/MAPK pathway thus contributing to cell survival [25-27].

\section{EBV Lytic Reactivation}

Under certain circumstances the latent virus can be reactivated, changing from its dormant non-replicating stage into its lytic phase 
which ultimately results in production of new infectious virions. The 3-step lytic cascade starts with activating the expression of immediate early (IE) transactivator proteins encoded in BZLF1 (ZEBRA or Zta) and BRLF1 (Rta) (Figure 1, middle) [28]. Many cellular and viral proteins modulate the induction and function of ZEBRA and Rta in disruption of latency and this is cell type dependent, as will be discussed later in more detail. The BZLF1 gene encodes a sequence specific DNA-binding protein (ZEBRA), which is a member of the bZIP family of leucine-zipper transactivators. The BZLF1 promoter $(\mathrm{Zp})$ is a $233 \mathrm{bp}$ long sequence on the EBV genome which generally is heavily methylated and transcriptionally silenced in the viral latent state. Its activity is controlled by the balance between (host) (de-) methylating and (de-)acetylating enzyme activities regulating access and activities of cellular transcription factors on $\mathrm{Zp}$. Murata et al. summarized cis- and trans-elements playing a role in $\mathrm{Zp}$ regulation and the balanced interaction between positive and negative regulators that governs the switch from latent to lytic phase (Figure 2) [28]. For $\mathrm{Zta}$ expression and activity the methylation of EBV DNA is required [29-32]. ZEBRA can bind to at least 32 variants of ZEBRA-responsive elements (ZRE's) present in the $\mathrm{Zp}$ and in promoters of EBV early genes [33,34]. Thus, ZEBRA together with endogenous host cell specific cellular transcription factors activate $\mathrm{Zp}$ in an auto-stimulatory loop [35]. The BZLF1 gene can also be activated by the BRLF1 encoded transactivator Rta. Reversely, ZEBRA drives expression of Rta (and $\mathrm{Na}$ - another viral protein encoded by BRRF1), which results in Zta-RtaBRRF1 synergy forming a positive feedback loop to activate $\mathrm{Zp} \mathrm{[36-38].}$ The BMLF1 gene product (EB2 or I'ta) is another IE protein, which is involved in nuclear export and cytoplasmic stabilization of non-spliced RNA transcripts. It increases the level of viral and cellular protein(s) required for stable Zta expression [39].

Once induced, these IE products cause cell-cycle arrest in G1 phase and cooperate to induce the second step in the reactivation cascade, i.e., the early (E) phase $[35,40,41]$, ultimately inducing the entire lytic cascade activation and virus replication (Figure 1, right side) [42]. It has been demonstrated that in some EBV-associated malignancies, sporadic tumor cells show detectable ZEBRA expression. Since true late lytic gene transcription in EBV associated tumor cells is mostly absent, these low levels of ZEBRA expression probably reflect partial (abortive) activation of the lytic phase.

During reactivation a plethora of viral gene products is expressed, starting with early gene products, such as EBV-DNA binding proteins, helicase (together forming the complex with early antigen diffuse protein EA-D), thymidine kinase (TK), protein kinase (PK) and other enzymes involved in nucleotide metabolism, all preparing the host cell for viral DNA replication by the viral DNA-polymerase (DNApol; BALF5) $[28,41]$. In the third phase of viral reactivation, and closely related to synthesis of new non-methylated viral DNA templates, the late structural proteins are expressed that travel into the nucleus to incorporate newly synthesized linear viral DNA into stable capsid structures. These are subsequently released into the cytoplasm to acquire an envelope by budding into Golgi membranes and forming new mature infectious EBV virions that are secreted into the extracellular space. The newly synthesized viral genome is linear and epigenetically unmodified. The lytic phase is essential part of EBV life cycle, since the production of infectious viral particles that allows the virus to be transmitted from cell to cell and host to host.

\section{Molecular Triggers for EBV Reactivation}

Although in EBV-associated malignancies as well as in infected memory B cells of healthy carriers latency is the mainstream of EBV infection, there are indications that bursts of spontaneous (recurrent) reactivation in fact may play a role in EBV persistence and pathogenesis [41]. Distinct cellular differentiation factors regulate spontaneous EBV reactivation and this is highly cell-type dependent [43]. Activation pathways will be detailed later in this review. BLIMP1 is one of the key players in both epithelial and B-cell differentiation and was recently shown to facilitate EBV reactivation from latency in both cell backgrounds [44]. Together with BLIMP1, another differentiationdependent cellular transcription factor, Kruppel-like factor4 (KLF4) was recently reported to play a critical role in epithelial cells [45]. Modifications of EBV genome, such as 5-hydroxymethylation of cytosine (important in epithelial-cell differentiation) may also affect EBV lytic reactivation and is regulated by cellular TET enzymes [46]. Expression of virus maintenance factor EBNA1 inhibits spontaneous reactivation, but facilitates lytic cycle after initial reactivation in gastric carcinoma cells AGS-BX1 [47]. Serological studies in NPC-risk populations suggest that EBV reactivation occurs a long time before clinical diagnosis of NPC with increasing EBV-specific IgA antibody responses paralleling NPC tumor development [48-50]. It has been reported that certain nutritional habits and/or environmental risk factors may have substantial impact on NPC development [51-54]. A recent study demonstrated increased tumorogenicity after N-nitroso compounds (commonly found in food in high-risk NPC regions) induced recurrent EBV reactivation in NPC cells and mouse model [55]. In addition, regular consumption of rancid fat and certain spicy food components have been linked to NPC risk [56].

Throughout the years, multiple agents have been described to trigger EBV lytic induction, such as radiation and different chemotherapeutical agents - alone or in combination with histone deacetylase inhibitors HDACi-s [57,58]. Proteins produced in this phase (viral neo-antigens) are highly immunogenic and can be recognised and targeted by the immune system $[4,5]$. Furthermore, the reactivation of the EBV lytic

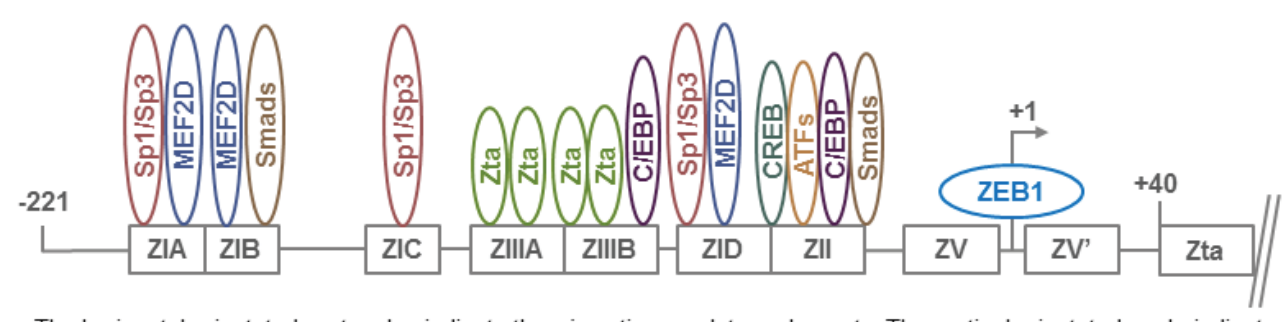

The horizontal orientated rectangles indicate the cis-acting regulatory elements. The vertical orientated ovals indicate their trans-acting factors. ZEB1 binds via its two zinc-finger domains to ZV and ZV'. Image based on the figure of Yu et al, PLOS Path 2007.

Figure 2: Schematic close-up of the regulatory elements within the Zebra promoter (Zp). 
cascade leads to the expression of viral enzymes (thymidine and protein kinases, TK and PK respectively) that may sensitize tumour cells to antiviral treatment [35]. These findings have led to the development of novel therapeutic approaches aiming at EBV reactivation.

\section{Therapeutic Options Exploiting the EBV Lytic Cycle}

New strategies are emerging for virus-targeted therapy to treat EBV-associated malignancies, generally consisting of two components. The first step is aimed at initiating virus reactivation and triggering recognition of the tumour cells by the immune system [originally described by Moolten in 1986] [59]. The second step is the administration of an antiviral drug which can be metabolised exclusively in cells expressing viral lytic cycle proteins [60].

In previous studies, variable combinations of drugs/reagents were tested on different EBV-driven tumour cell lines in vitro and in vivo to investigate the most potent effect on reactivating the latent viral genome into lytic gene expression. For example, plasmids encoding immediate early lytic genes were transfected in a truly latent EBVinfected Burkitt Lymphoma (BL) cell line. After expression of these lytic proteins an antiviral compound was administered, which resulted in a decreased growth of cells [60]. Activation of Ganciclovir (GCV) requires conversion to monophosphate by EBV-encoded kinases, mainly BXLF1 encoded TK and BGLF4 encoded PK [61], followed by two additional phosphorylations by host cell enzymes and formation of cytotoxic triphosphate form which is incorporated in the growing DNA strand causing a "DNA chain termination". Therefore, only lytically infected but not latently infected EBV-positive tumor cells are sensitive to the cytotoxic effects of GCV [62]. Chemotherapy combined with HDACi-s reduced the growth of EBV-positive tumours in a mouse lymphoma model [63]. This effect is amplified by the addition of an antiviral drug [64]. We and others have studied EBV reactivation in the naturally infected NPC epithelial cell line C666.1 and observed synergistic cytotoxic effects of the combination of gemcitabine (GCb), valproic acid (VPA) for inducing viral reactivation and (val)Ganciclovir as antiviral compound [65-67]. This Cytolytic Virus Activation Therapy (CLVA) for EBV-associated malignancies was subsequently used with promising results in three Dutch NPC patients [65]. A recent continuation of this Phase-I/-II study on eight end-stage NPC patients showed that drug combination was well tolerated and induced clinical responses in patients naïve to $\mathrm{GCb}[68]$.

In this review effective (combinations of) EBV lytic inducers are presented. The chemical structure of compounds used as virus lytic inducers are shown in (Supplementary) Figure 3a-c. Effectiveness was demonstrated by various techniques (presented in Tables 1-4) including detection of EBV lytic protein and mRNA expression, as well as functional characteristics such as apoptosis induction and sensitivity to antiviral treatment. The mechanism of action of the various components is indicated and the consequence of adding an antiviral drug is also described. This systematic overview focuses on efficacy of compounds for viral reactivation in various in vitro models. Highlighted are DNA damage responses and host-susceptibility factors. Recently more clinically oriented overviews on EBV targeted therapeutic strategies were published $[69,70]$.

\section{Pharmacological Inducers of EBV Lytic Phase}

\section{Histone deacetylase inhibitors}

Histone deacetylase inhibitors (HDACi-s) represent a well-known group of drugs that modify the acetylation status of several cellular (and viral) proteins. According to their chemical structure they can be categorized into different classes, including short chain fatty acids, hydroxamates, benzamides, cyclic tetrapeptides and epoxides [71]. These compounds modulate chromatin structure via inhibition of histone acetylation, but also target several non-histone substrates. HDACi-s are structurally diverse compounds with biological effects ranging from cell death induction, differentiation, angiogenesis inhibition to modulation of immune response. In general, HDACi-s have been shown to have potent anticancer activities including reversing aberrant epigenetic changes associated with cancer [72,73]. Several combination strategies vis-à-vis with HDACi-s have been tested and validated in preclinical studies, either as chemo sensitizing agents in standard chemotherapy regime or in combination with DNA methyltransferase inhibitors (DNMTi-s) in the context of "epigenetic therapies" aiming to revert epigenetic alterations found in cancer cells. Pan-HDACi-s, which inhibit 11 HDAC isoforms, are widely used to induce EBV lytic cycle. Here we discuss EBV-specific lytic induction capacities of commonly used HDACi-s (VPA, NaB, TSA and SAHA) and results are summarized in Table 1. HDAC-inhibition does not necessarily lead to virus reactivation in all EBV-positive cell lines, as the EBV reactivation process by chromatin modulation is cell type dependent. Chemically-triggered expression of viral transactivator (Zta/Rta) induces chromatin remodelling at target promoters, leading to restructuring of nucleosomes and loss of polycomb-repression which initiates the EBV lytic cascade [74]. Thus, HDACi-s can selectively modulate viral gene expression by influencing the accessibility of enhancer elements in viral promotors for host transcription factors, see Figure 2. The level and presence of these regulatory elements and host HDACi and DNMT activities all influence lytic induction response and are largely cell type specific.

\section{Valproic acid}

VPA, 2-propylpetanoic acid, sodium valproate is a short-branchedchain fatty acid that has been widely used in the clinic as anticonvulsant and mood stabilizer for decades. Currently, there are numerous VPAbased clinical trials for treatment of a wide range of malignancies. Although other mechanisms may also contribute to VPA-induced anticancer effects, the inhibition of histone deacetylases (HDACs) appears to play a central role. VPA is a class I and II HDACi with preference for class I inhibition, but it has also been reported as inducer of DNA demethylation in non-dividing cells [75-77]. Due to its HDACiproperty, VPA treatment can induce lytic viral gene expression in some EBV positive tumor models and this effect appears to be dose and timedependent. VPA itself only weakly activates lytic EBV gene expression, but it strongly enhances the ability of chemotherapeutic agents (such as 5-FU and gemcitabine) to reactivate EBV in both epithelial and lymphoid tumour cells $[63,65]$. VPA may promote lytic induction by increasing the acetylation state of the chromatin surrounding the episomal viral genome, thus providing opening of the genome for access by cellular transcription factors and by epigenetic reprogramming via demethylation of host regulatory gene promoters $[63,76,78,79]$. However opening of chromatin structure is not equally effective for EBV lytic reactivation in different cell backgrounds. In vitro studies showed the ability of VPA to regulate epigenetic modifications of the EBV genome and chromatin modulating proteins in breast cancer cells [80]. VPA alone is not sufficient to induce lytic phase in truly latent HH514 BL cells, despite inducing hyperacetylation of $\mathrm{H} 3$ in contrast to TSA and AZC and we found the same for C666.1 NPC cells $[65,79]$.

Iwata et al. analyzed EBV-positive $\mathrm{T}$ and $\mathrm{NK}$ cell lines for expression of lytic genes encoding Zta and gp350/220, after exposure to VPA for 24 and 48 hours [78]. RT-PCR showed no significant difference between VPA-treated cells and controls. Although VPA induced apoptosis and cell cycle arrest, it did not trigger a lytic switch. Since the killing effect of 
Citation: Novalić Z, van Rossen TM, Greijer AE, Middeldorp JM (2016) Agents and Approaches for Lytic Induction Therapy of Epstein-Barr Virus Associated Malignancies. Med chem (Los Angeles) 6: 449-466. doi:10.4172/2161-0444.1000384

\begin{tabular}{|c|c|c|c|c|c|c|c|c|}
\hline Drug & $\begin{array}{c}\text { Cell line } \\
\text { (tumor origin) }\end{array}$ & Assays & Detected proteins & $+\mathrm{GCV} ?$ & $\begin{array}{c}\text { Result } \\
\text { on lytic } \\
\text { induction }\end{array}$ & $\begin{array}{l}\text { (Optimal) drug } \\
\text { concentration }\end{array}$ & $\begin{array}{l}\text { Exposure } \\
\text { time }\end{array}$ & Ref. \\
\hline \multirow[t]{2}{*}{ VPA } & AGS-BX1 (GC) & WB & BZLF1, BRLF1, BMRF1 & No & + & $1-10 \mathrm{mmol} / \mathrm{L}$ & $48 \mathrm{~h}$ & [84] \\
\hline & & IF & BZLF1 & No & + & $1-10 \mathrm{mmol} / \mathrm{L}$ & $48 \mathrm{~h}$ & [84] \\
\hline $\mathrm{VPA}+5-\mathrm{FU}$ & $\begin{array}{c}\text { C666.1 (NPC); AGS- } \\
\text { EBV (GC) }\end{array}$ & WB & BZLF1, BRLF1, BMRF1 & No & + & $\begin{array}{c}0.3 \mathrm{mmol} / \mathrm{L} \mathrm{VPA}, 1 \mu \mathrm{g} / \\
\mathrm{mL} 5-\mathrm{FU}\end{array}$ & $48 \mathrm{~h}$ & [63] \\
\hline VPA+CDDP & AGS-EBV (GC) & IF & BMFR1 & No & + & $\begin{array}{c}0.3 \mathrm{mmol} / \mathrm{L} \text { VPA, } 0.25 \\
\mu \mathrm{g} / \mathrm{mL} \text { CDDP }\end{array}$ & $48 \mathrm{~h}$ & [63] \\
\hline \multirow[t]{3}{*}{$\mathrm{NaB}$} & AGS-BX1(GC) & WB & BZLF1, BRLF1, BMRF1 & No & + & $0.5-3 \mathrm{mmol} / \mathrm{L}$ & $48 \mathrm{~h}$ & [84] \\
\hline & & IF & BZLF1 & No & + & $1.5 \mathrm{mmol} / \mathrm{L}$ & $48 \mathrm{~h}$ & [84] \\
\hline & AGS-Akata (GC) & WB & BZLF1, BRLF1, BMRF1 & No & + & $3 \mathrm{mmol} / \mathrm{L}$ & $48 \mathrm{~h}$ & [123] \\
\hline \multirow[t]{5}{*}{ NaB/TSA/TPA } & HH514-16 (BL) & NB & BZLF1, BRLF1 & No & ++ & $\begin{array}{c}3 \mathrm{mmol} / \mathrm{L} \mathrm{NaB} \\
5 \mu \mathrm{mol} / \mathrm{L} \mathrm{TSA}\end{array}$ & $8 \mathrm{~h}$ & [85] \\
\hline & B95-8 (LCL) & NB & BZLF1, BRLF1 & No & $\begin{array}{l}+ \text { TPA, } \\
-\mathrm{NaB}\end{array}$ & $\begin{array}{l}3 \mathrm{mmol} / \mathrm{L} \mathrm{NaB} \\
20 \mathrm{ng} / \mathrm{mL} \mathrm{TPA}\end{array}$ & $8 \mathrm{~h}$ & {$[85]$} \\
\hline & $\begin{array}{c}\text { BC-1 (EBV/KSHV } \\
\text { LCL) }\end{array}$ & NB & BZLF1, BRLF1 & No & $\begin{array}{l}+\mathrm{TPA} \\
-\mathrm{NaB}\end{array}$ & $\begin{array}{l}3 \mathrm{mmol} / \mathrm{L} \mathrm{NaB}, \\
20 \mathrm{ng} / \mathrm{mL} \mathrm{TPA}\end{array}$ & $8 \mathrm{~h}$ & [85] \\
\hline & $\begin{array}{c}\text { BC-1 (EBV/KSHV } \\
\text { LCL); HH514-16 (BL) }\end{array}$ & qRT-PCR & BRLF1 & No & + & $5 \mu \mathrm{mol} / \mathrm{L}$ TSA & $8 \mathrm{~h} ; 9 \mathrm{~h}$ & [85] \\
\hline & $\begin{array}{c}\mathrm{BC}-1 \text { (EBV/KSHV } \\
\mathrm{LCL})\end{array}$ & WB & BRLF1 & No & $\begin{array}{l}+ \text { TPA, } \\
+/-\mathrm{NaBB}\end{array}$ & $\begin{array}{l}3 \mathrm{mmol} / \mathrm{L} \mathrm{NaB}, \\
20 \mathrm{ng} / \mathrm{mL} \mathrm{TPA}\end{array}$ & $24 \mathrm{~h}$ & [85] \\
\hline $\mathrm{NaB} / \mathrm{TPA}$ & AGS-BX1 (GC) & WB & BZLF1, BRFL1, BMRF1 & No & + & $\begin{array}{c}2.5 \mathrm{mmol} / \mathrm{L} \mathrm{NaB}, 20 \mathrm{ng} / \\
\mathrm{mL} \text { TPA }\end{array}$ & $24 \mathrm{~h}$ & [182] \\
\hline $\begin{array}{c}\mathrm{NaB}+ \\
\text { y-irradiation }\end{array}$ & $\begin{array}{c}\text { LCLs; EBV + BL } \\
\text { (Jijoye, Akata); AGS- } \\
\text { EBV (GC) }\end{array}$ & WB & BZRF1, BMLF1 & No & + & $2.5 \mathrm{mmol} / \mathrm{L}$ & $48 \mathrm{~h}$ & [57] \\
\hline \multirow[t]{4}{*}{ TSA } & SNU-1103 (LCL) & WB & $\begin{array}{l}\text { BZLF1, BRLF1, BMRF1, } \\
\text { BALF5, BBLF2/3 }\end{array}$ & No & + & $100-300 \mathrm{nmol} / \mathrm{L}$ & $48 \mathrm{~h}$ & [83] \\
\hline & & IF & BZLF1, BMRF1, gp110, gp350 & No & + & $100-300 \mathrm{nmol} / \mathrm{L}$ & $48 \mathrm{~h}$ & [83] \\
\hline & AGS-BX1 (GC) & $\begin{array}{l}\text { WB } \\
\text { IF }\end{array}$ & BZLF1,BRLF1, BMRF1 BZLF1 & $\begin{array}{l}\text { No } \\
\text { No }\end{array}$ & $\begin{array}{l}+ \\
+\end{array}$ & $\begin{array}{l}100 \mathrm{nmol} / \mathrm{L} \\
100 \mathrm{nmol} / \mathrm{L}\end{array}$ & $\begin{array}{l}48 \mathrm{~h} \\
48 \mathrm{~h}\end{array}$ & $\begin{array}{l}{[84]} \\
{[84]}\end{array}$ \\
\hline & SNU-719 (GC) & WB & BZLF1, BRLF1, BMRF1 & Yes $(+)$ & + & $\begin{array}{c}0.5 \text { or } 5 \mathrm{nmol} / \mathrm{L}, 10 \mu \mathrm{g} / \\
\mathrm{mL} \mathrm{GCV}\end{array}$ & $6 \mathrm{~d}$ & [86] \\
\hline \multirow[t]{10}{*}{ SAHA } & AGS-Akata (GC) & WB & BZLF1, BMRF1 & No & + & $5 \mu \mathrm{mol} / \mathrm{L}$ & $48 \mathrm{~h}$ & [123] \\
\hline & $\begin{array}{c}\text { HK1-EBV (NPC); HA } \\
\text { (NPC); HONE-EBV } \\
\text { (NPC) }\end{array}$ & WB & $\begin{array}{l}\text { BZLF1, BRLF1, } \\
\text { BMRF1,gp350/220 }\end{array}$ & No & + & $2.5-20 \mu \mathrm{mol} / \mathrm{L}$ & $48 \mathrm{~h}$ & [92] \\
\hline & C666.1 (NPC) & WB & BZLF1, BRLF1, BMRF1 & No & + & $20-40 \mu \mathrm{mol} / \mathrm{L}$ & $96 \mathrm{~h}$ & [92] \\
\hline & HA (NPC) & IF & $\begin{array}{l}\text { BZLF1, BRLF1, } \\
\text { BMRF1,gp350/220 }\end{array}$ & No & + & $5 \mu \mathrm{mol} / \mathrm{L}$ & $48 \mathrm{~h}$ & [92] \\
\hline & HA (NPC) & FACS & BZLF1,BMRF1,gp350/220 & No & + & $5 \mu \mathrm{mol} / \mathrm{L}$ & $2-3 d$ & [92] \\
\hline & AGS-BX1 (GC) & WB & $\begin{array}{c}\text { BZLF1,BRLF1,BMRF1, VCA- } \\
\text { p40,gp350/220 }\end{array}$ & No & + & $0.5-10 \mu \mathrm{mol} / \mathrm{L}$ & $48 \mathrm{~h}$ & [84] \\
\hline & HONE-EBV (NPC) & IF & BZLF1,BMRF1,gp350/220 & No & + & $5 \mu \mathrm{mol} / \mathrm{L}$ & $48 \mathrm{~h}$ & [84] \\
\hline & AGS-BX1 (GC) & IF & BZLF1,BMRF1,gp350/220 & No & + & $10 \mu \mathrm{mol} / \mathrm{L}$ & $48 \mathrm{~h}$ & [84] \\
\hline & HA (NPC) & WB & $\begin{array}{l}\text { BZLF1, BRLF1, BMRF1, } \\
\text { gp350/220 }\end{array}$ & No & + & $5 \mu \mathrm{mol} / \mathrm{L}$ & $24-48 \mathrm{~h}$ & [93] \\
\hline & C666.1 (NPC) & WB & $\begin{array}{l}\text { BZLF1, BRLF1, BMRF1, } \\
\text { gp350/220 }\end{array}$ & No & - & $5 \mu \mathrm{mol} / \mathrm{L}$ & 24- $48 \mathrm{~h}$ & [93] \\
\hline $\mathrm{SAHA}+\mathrm{BTZ}$ & HA (NPC) & WB & $\begin{array}{c}\text { BZLF1, BRLF1, BMRF1, } \\
\text { gp350/220 }\end{array}$ & No & + & $\begin{array}{c}5 \mu \mathrm{mol} / \mathrm{L} \text { SAHA, } 30 \\
\mathrm{nmol} / \mathrm{L} \mathrm{BTz}\end{array}$ & $24-48 \mathrm{~h}$ & [93] \\
\hline
\end{tabular}

The column "Result" displays the effect of the drug on lytic induction: an increased (+), inhibited (-) or no significant $(0)$ effect. The column "+GCV" indicates whether the drug described is combined with GCV (Ganciclovir) or not. If a "Yes" is noted in this column; the subsequent symbol shows if the addition of GCV has a positive (+), negative (-) or no effect $(0)$ on the amount of cell killing. WB=Western blot; NB=Northern blot; IF=Immunofluorescence.

Table 1: Summary of HDACi-s (alone or in combination with TPA/chemo or other stimuli) effects on EBV Iytic induction in cancer cell lines of epithelial and lymphoid origin. 
VPA was limited, the combination of VPA and BTz was tested, and an additive killing effect demonstrated. Subsequently, exposure of PBMCs from three patients with EBV-associated T or NK lymphoproliferative diseases to VPA was tested. As expected, VPA resulted in a higher killing of EBV-infected cells compared to uninfected cells, and the effect was increased when VPA was combined with BTz. Xu et al. and Nebbioso et al. summarized HDACi's used in clinical trials focused on mechanisms of HDACi-induced cell death $[81,82]$.

\section{Trichostatin A}

TSA is a"classic" epigenetic modifier and antifungal antibiotic with cytostatic and differentiating properties. TSA treatment is causing (a dose-dependent) cell cycle arrest and apoptosis, and effectively inducing lytic replication (in EBV-transformed B cells) and epithelial cells [83-85]. Enhanced EBV lytic induction by TSA when combined with 5'-azacytidine and GCV in GC cell lines and in tumors originating from epithelial, NK and B cells, was confirmed by expression of BZLF1 and BRLF1 and accompanied by promoter demethylation [86,87]. Dose-dependent TSA induction of EBV lytic phase as well as cell cycle arrest and apoptosis was reported by Seo et al. in a latency type III EBVtransformed LCL cell line [83]. Nishikawa et al. reported increased synthesis of Zta and up-regulation of LMP1 protein expression by HDACi-s (NaB and TSA) in in vitro infected NPC cell line TWO3EBV [88].

\section{Suberoylanilide hydroxamic acid}

(SAHA, Vorinostat, Zolinza) is a potent pan-HDACi, altering gene transcription and inducing cell cycle arrest, differentiation and apoptosis. It binds to the active site of HDAC-s and serves as a chelator for zinc ions, blocking the enzymatic activity. SAHA is very strong inducer of the EBV lytic phase and treatment does not require combination with chemotherapeutics. It is the first HDACi to be approved for clinical use in treating patients with malignancies (e.g., cutaneous T cell lymphoma) [89].

Hui et al. reported significant lytic induction in AGS-BX1 cells (GC, latency II) mediated by SAHA $(\mu \mathrm{M})$, TSA $(\mu \mathrm{M}), \mathrm{NaB}(\mathrm{mM})$ or VPA $(\mathrm{mM})$, with SAHA being the most potent inducer, but found only weak effect at similar drug levels in AK2003 cells (BL, latency I) while no lytic induction was seen in LCLs (B-blast latency III) [84]. In these experiments, SAHA was also found to up-regulate expression of EBVencoded LMP1. HDACi-s are known to induce LMP1 in lymphoma cells which is mediated via NF- $\kappa \mathrm{B}$ activation as suggested by Park and Faller [90]. Treatment of EBV-positive BL cells with NaB-induced apoptosis via induction of the viral lytic program and resulted in an increase in NF- $\kappa B$ DNA binding [91]. Hui et al. further reported that SAHA treatment of various NPC cell lines (HK1-EBV, HONE1-EBV, HA and C666.1) induced Zta/Rta expression and demonstrated its strong pro-apoptotic effects, following early activation of the EBV lytic phase [92]. SAHA treatment was also effective in suppressing C666.1-derived tumor growth in vivo in nude mice. The same group further studied effects of SAHA and/or bortezomib (BTz; inhibitor of 26S-proteasome, pro-apoptotic agent) in NPC cell lines (HA, C666.1) [93]. In these experiments SAHA significantly induced Zta expression and the addition of BTz reduced expression of SAHA-induced Zta (in HA cells). BTz also disrupted SAHA-induced EBV replication, while potentiating SAHA's induction of apoptosis. The authors suggested that use of SAHA/BTz combination could be suitable for treatment of $\mathrm{BL}$ and PTLDs (when EBV shows a Cp/Wp-restricted latency) [94]. This combination synergistically induced the apoptosis and killing of Wp-restricted BL and LCLs (latency III) and suppressed the growth of Wp-restricted BL xenografts in nude mice, but did not affect Qp-driven latency I BL cells.

\section{Romidepsin}

(Istodax ${ }^{\oplus}$, NSC 630176, FR901228, FK228, Depsipeptide) is a bicyclic pentapeptide isolated from the soil bacterium Chromobacterium violaceum. This class I specific HDACi has been FDA approved for the treatment of cutaneous T cell lymphoma (CTCL) $[95,96]$. It is very efficient in inducing EBV lytic induction in vitro and in vivo in both NPC and GC epithelial tumor cells (nM concentrations), and in GCV mediated enhanced cell death [97]. However, in recent pilot study in patients with extranodal natural killer (NK)/T-cell lymphoma (ENKTL), serious adverse events were reported and suggested that romidepsin may cause too rapid EBV reactivation [98]. Further trials should include simultaneous administration of GCV with romidepsin.

\section{Sodium butyrate}

$(\mathrm{NaB} / \mathrm{SB})$ is a short-chain fatty acid which is altering gene expression and arresting cell proliferation by inhibition of the chromatinremodeling activity of HDAC-s and histone hyperacetylation. It is commonly used as EBV lytic inducer often in combination with other agents, such as TPA or TSA. The early experiments showed that a lowlevel of lytic induction (EA) was obtained after the addition of $\mathrm{NaB}$ (or TPA alone) in Raji and NC37 cell lines, while the simultaneous presence of both compounds resulted in a significantly higher percentage of EBV reactivating cells [99]. In combination with GCV, butyrate is shown to induce killing of EBV-positive tumor cells in vitro and beneficial effects were obtained in lymphoma treatment $[58,100]$.

\section{Phorbol esters (TPA/PMA) combined with HDACi-s}

Themost commonlyused phorbol esteris 12-O-tradecanoylphorbol13-acetate (TPA), also known as phorbol-12-myristate-13-acetate (PMA). Zur Hausen et al. first reported TPA-induced EBV lytic cycle gene expression [101]. In B cells, TPA-mediated lytic induction requires activation of cellular protein kinase $\mathrm{C}$ (PKC) [102]. TPA treatment induces lytic EBV gene transcription in some cell lines by quick activation of PKC, but this is not an obligatory event suggesting more complex regulation of lytic induction [103,104]. TPA-mediated EBV lytic induction is strongly enhanced by the addition of sodium butyrate, and therefore the TPA/SB combination is widely used. The mechanism of TPA reactivation of EBV has been studied in depth (see later section), and antagonism between some HDACi-s (VPA) was reported [105]. Moreover, the capacity of other HDACi-s including the benzamide derivative Entinostat (MS 275), cyclic tetrapeptide Apicidin, cyclic depsipeptide Largazole (from a marine cyanobacterium), hydroxamic acids Oxamflatin, Scriptaid, Panobinostat (LBH 589) and Belinostat (PXD 101) were studied in the context of EBV lytic induction and cytotoxicity, but available (clinical trial) data are limited [58,105].

Effects of combined HDACi-s and chemotherapeutics on EBV reactivation are summarized in Table 1.

\section{HDACi-s and Susceptibility to Ganciclovir for Induction of EBV Lytic Phase}

Antiviral (val)Ganciclovir (GCV) treatment alone is not effective for treating EBV-associated malignancies, since tumor cells harbouring latent $\mathrm{EBV}$ do not express viral kinases (PK/TK), required for conversion of this nucleoside analogue into its cytotoxic form. TK/ PK enzyme activity requires initiation of the EBV lytic cycle through $\mathrm{Zta} / \mathrm{Rta}$ expression from the latent viral genome. Park and Faller (2002) demonstrated that EBV reactivation in a number of EBVpositive BL lines is induced by butyrate or other HDACi-s alone [90]. Among several different EBV-positive BL lines studied (Akata, 
Daudi, JY, Namalwa), P3HR-1 was the cell line most responsive to HDACi-s. Mentzer (2001) applied this strategy for treating EBVassociated lymphoma/ PTLD using arginine butyrate combined with GCV in clinic, based on their finding on arginine butyrate-induced susceptibility to GCV $[64,106]$. The promising results of this study led to phase I-II trial demonstrating that this combination regime was well-tolerated and induced significant biologic activity in recurrent EBV-positive lymphoid malignancies [107].

In the case-report study of Stevens et al. a combination of 5-FU/ VPA was administered to a young EBV-positive NPC patient with advanced recurrent disease to induce EBV lytic induction, followed by (val)GCV treatment. This treatment resulted in detectable levels of EBV-DNA load in circulation, due to release of viral genomes from the EBV positive tumor [108]. Jones et al. reported another case-study where the combination of VPA and GCV resulted in detectable EBVDNA load in plasma in patient with relapsed EBV-positive Diffuse Large B cell Lymphoma (DLBCL) [109]. Increased expression of IE proteins by addition of TSA in combination with GCV was reported by Jung et al. [110]. Ghosh et al. tested different HDACi-s in EBV-positive lymphoma cells and found that with the exception of SAHA and PXD101, all the other tested (butyrate, valproate, Oxamflatin, LBH 589 and Scriptaid) were effective in sensitization the EBV positive tumor cells to GCV at low (nM) concentrations [58].

These observations strongly point to the beneficial effect of combining EBV lytic cycle inducers together with antiviral compounds such as (val)Ganciclovir, to not only prevent full viral replication and spread in vivo [98], but more importantly, to kill proliferating EBVinfected cells by DNA chain termination.

\section{DNA Demethylating Agents}

During viral latency the ZEBRA promoter $(\mathrm{Zp})$ is in an inactive, hypermethylated state $[111,112]$. The hypermethylation is probably caused by deregulation of methyltransferases in early tumorigenesis, driven by viral factors such as LMP1 [113-115]. Induction of EBV lytic cycle gene expression is probably only possible after the release of EBV genomic silencing by both promoter demethylation and histone acetylation [79]. Once persistent in the host cell EBV is interfering with cellular pathways and deregulating diverse homeostatic cellular functions $[66,116,117]$. In EBV-associated cancers viral genome is subject to extensive epigenetic regulation and viral promoters are heavily methylated, but such a virus is still powerful in mimicking the effect of growth, transcription and anti-apoptotic factors. On the other hand, complex mechanisms in the host cell are employed to suppress the ability of cellular transcription factors to activate the expression of the EBV IE gene promoters, in order to maintain virus in the latent form of infection [74]. The genomes of EBV-infected tumor cells and their normal counterparts have differing epigenetic patterns, due to diverse epigenetic dysregulation. Hypermethylation of several host genes has been described in EBV-associated cancers $[118,119]$. Methylation, to some extent, might be beneficial for selectivity of BZLF1 activation, since Zta preferably binds to methylated domains of BRLF1 promoter, thereby initiating the lytic cascade $[28,33]$.

Demethylating agents, such as 5-azacytidine (5-aza-CR) have been studied, in order to enhance the effects of lytic induction. The results showed increased lytic viral gene expression in Burkitt's lymphoma cell lines [120], but not in lymphoblastoid cell lines [62], indicating that other factors besides methylation might be involved in desensitizing of EBV early gene promoters. The effect of 5-aza-2'deoxycytidine (5-AZA) on lytic induction is investigated in several studies too. BenSasson and Klein (1981) found an 8 times higher EA-gene expression in BL cells treated with this drug, compared to spontaneous levels, evaluated with IF [121]. This was confirmed in another BL cell line by Moore et al. [122]. Feng et al. also showed that 5-AZA caused lytic induction in a BL cell line, but no effect was seen in three different LCL cell lines [62]. Cell viability was not impaired by the drug, except when combined with GCV [86]. In addition, in an epithelial cell line of GC origin, results were similar, and a combination of 5-AZA with GCV even showed an enhanced effect on inducing cell death [110]. Details are summarized in Table 2.

\section{Chemotherapeutics}

The ability of particular chemotherapeutic agent to induce lytic EBV gene expression is mediated by variety of signal transduction pathways and their synergistic engagement, importantly, is dependent on cell type [66]. Details are summarized in Table 3.

Multiple studies show that Gemcitabine (GCb), a nucleoside analog, is able to switch on lytic induction in a subset of EBV-positive cell lines, including three types of LCL, Raji (BL), AGS-BX1, SNU-719 (GC) and C666.1 (NPC) $[62,63,65,67]$. In EBVaGC, GCb was found to act as a lytic phase inducer by activating the ataxia telangiectasiamutated (ATM)/p53 genotoxic stress pathway [123]. Overall, GCb turns out to be a potent EBV-lytic phase inducer and this effect could even be increased by the addition of VPA or the subsequent administration of GCV $[62,63,65]$. Interestingly, the addition of

\begin{tabular}{|c|c|c|c|c|c|c|c|c|}
\hline Drug & $\begin{array}{c}\text { Cell line } \\
\text { (tumor origin) }\end{array}$ & Assays & $\begin{array}{l}\text { Detected } \\
\text { proteins }\end{array}$ & $+\mathrm{GCV} ?$ & $\begin{array}{c}\text { Result on lytic } \\
\text { induction }\end{array}$ & $\begin{array}{l}\text { (Optimal) drug } \\
\text { concentration }\end{array}$ & $\begin{array}{c}\text { (Optimal) } \\
\text { exposure time }\end{array}$ & Ref. \\
\hline \multirow[t]{5}{*}{ 5-AZA } & Daudi (BL) & IF & EA, VCA & No & + & $25 \mu \mathrm{mol} / \mathrm{L}$ & $6 \mathrm{~h}$ & [121] \\
\hline & Rael (BL) & $\mathrm{IHC}$ & Zta, VCA & No & + & $15 \mathrm{mmol} / \mathrm{L}$ & $48 \mathrm{~h}$ & [122] \\
\hline & SNU-719 (GC) & WB & $\mathrm{IE}$ & Yes (+) & + & $\begin{array}{c}0.5 \text { or } 5 \mu \mathrm{mol} / \mathrm{L}, 10 \mu \mathrm{g} / \\
\mathrm{mL} \mathrm{GCV}\end{array}$ & $6 \mathrm{~d}$ & {$[86]$} \\
\hline & $\begin{array}{c}\text { Raji (BL) } \\
\text { LCLs }\end{array}$ & $\begin{array}{l}\text { WB } \\
\text { WB }\end{array}$ & $\begin{array}{l}\text { IE } \\
\text { IE }\end{array}$ & $\begin{array}{l}\text { No } \\
\text { No }\end{array}$ & + & $\begin{array}{c}1 \mu \mathrm{mol} / \mathrm{L} \\
2.5 \mu \mathrm{mol} / \mathrm{L}\end{array}$ & $\begin{array}{l}5 d \\
5 d\end{array}$ & $\begin{array}{l}{[62]} \\
{[62]}\end{array}$ \\
\hline & Mutu-I & WB & $\mathrm{Z}, \mathrm{R}, \mathrm{BMRF} 1$ & No & + & $1 \mu \mathrm{mol} / \mathrm{L}$ & $2 d$ & [123] \\
\hline
\end{tabular}

The column "Result" displays the effect of the drug on lytic induction: an increased (+), inhibited (-) or no significant (0) effect. The column "+GCV" indicates whether the drug described is combined with GCV (Ganciclovir) or not. If a "Yes" is noted in this column; the subsequent symbol shows if the addition of GCV has a positive (+), negative (-) or no effect (0) on the amount of cell killing. WB=Western blot; IF=Immunofluorescence.

Table 2: Demethylating agent 5-aza-2'deoxycytidine effect on EBV lytic induction in cell lines of epithelial and lymphoid origin. 
Citation: Novalić Z, van Rossen TM, Greijer AE, Middeldorp JM (2016) Agents and Approaches for Lytic Induction Therapy of Epstein-Barr Virus Associated Malignancies. Med chem (Los Angeles) 6: 449-466. doi:10.4172/2161-0444.1000384

\begin{tabular}{|c|c|c|c|c|c|c|c|c|}
\hline Drug & $\begin{array}{c}\text { Cell line } \\
\text { (tumor origin) }\end{array}$ & Assays & $\begin{array}{l}\text { Detected } \\
\text { proteins }\end{array}$ & $+\mathrm{GCV} ?$ & Result & $\begin{array}{l}\text { (Optimal) drug } \\
\text { concentration }\end{array}$ & $\begin{array}{c}\text { (Optimal) } \\
\text { exposure time }\end{array}$ & Ref. \\
\hline \multirow[t]{4}{*}{$\mathrm{GCb}$} & LCLs, Raji (BL) & $\begin{array}{l}\text { WB } \\
\text { IF }\end{array}$ & $\begin{array}{c}\mathrm{IE} \\
\text { BMRF1 }\end{array}$ & $\begin{array}{l}\text { Yes (+) } \\
\text { (only LCLs) }\end{array}$ & + & $\begin{array}{c}1 \mu \mathrm{g} / \mathrm{mL} \\
10 \mu \mathrm{g} / \mathrm{mL} \mathrm{GCV}\end{array}$ & $5 \mathrm{~d}(\mathrm{WB}), 3 \mathrm{~d}(\mathrm{IF})$ & [62] \\
\hline & AGS-BX1 (GC) & $\begin{array}{l}\text { WB } \\
\text { PCR }\end{array}$ & $\begin{array}{l}\text { ZEBRA } \\
\text { ZEBRA }\end{array}$ & Yes $(+)$ & + & $\begin{array}{c}3 \mu \mathrm{mol} / \mathrm{L} \\
7.5-20 \mathrm{mmol} / \mathrm{L} \mathrm{GCV}\end{array}$ & $2 d$ & [65] \\
\hline & C666.1 (NPC) & $\begin{array}{l}\text { WB, IF } \\
\text { PCR }\end{array}$ & $\begin{array}{c}\text { ZEBRA } \\
\text { ZEBRA, TK, } \\
\text { PK, VCA-p18 }\end{array}$ & Yes $(+)$ & + & $\begin{array}{c}3 \mu \mathrm{mol} / \mathrm{L} \\
\mathrm{GCV} \text { concentration not } \\
\text { reported }\end{array}$ & $2 d$ & [65] \\
\hline & C666.1 (NPC) & WB & BMRF1 & No & 0 & $1 \mu \mathrm{g} / \mathrm{mL}$ & $2 d$ & [63] \\
\hline \multirow[t]{5}{*}{$5-\mathrm{FU}$} & LCLs, Raji (BL) & WB & IE & No & 0 & $5 \mu \mathrm{g} / \mathrm{mL}$ & $5 d$ & [62] \\
\hline & $\begin{array}{c}\text { AGS-EBV (GC), Akata } \\
\text { (BL) }\end{array}$ & $\begin{array}{l}\text { WB } \\
\text { FACS }\end{array}$ & $\begin{array}{l}\mathrm{IE}, \mathrm{E} \\
\text { BZLF1 }\end{array}$ & $\begin{array}{l}\text { Yes (+) } \\
\text { (only } \\
\text { AGS-EBV) }\end{array}$ & + & $\begin{array}{c}5 \mu \mathrm{g} / \mathrm{mL} \\
10 \mu \mathrm{g} / \mathrm{mL} \mathrm{GCV}\end{array}$ & $2 d$ & [126] \\
\hline & AGS-EBV (GC) & WB & BMRF1 & No & + & $1 \mu \mathrm{g} / \mathrm{mL}$ & $2 d$ & [63] \\
\hline & C666.1 (NPC) & WB & BMRF1 & No & 0 & $1 \mu \mathrm{g} / \mathrm{mL}$ & $2 d$ & [63] \\
\hline & SNU-719 (GC) & WB & E & Yes $(+)$ & + & $\begin{array}{c}0.1 \mu \mathrm{\mu g} / \mathrm{mL} \\
2 \mathrm{mg} / \mathrm{mL} \mathrm{GCV}\end{array}$ & $6 \mathrm{~d}$ & [110] \\
\hline \multirow[t]{2}{*}{ Dox } & LCLs, Raji (BL) & WB & IE & $\begin{array}{c}\text { Yes (+) } \\
\text { (only LCLs) }\end{array}$ & + & $\begin{array}{c}0.2 \mu \mathrm{mol} / \mathrm{L} \\
10 \mu \mathrm{g} / \mathrm{mL} \mathrm{GCV}\end{array}$ & $5 d$ & [62] \\
\hline & AGS-EBV (GC) & $\begin{array}{l}\text { WB } \\
\text { IF }\end{array}$ & $\begin{array}{l}\mathrm{IE}, \mathrm{E} \\
\mathrm{IE}, \mathrm{E}\end{array}$ & No & + & $\begin{array}{c}10-100 \mathrm{nmol} / \mathrm{L} \\
30 \mathrm{nmol} / \mathrm{L}\end{array}$ & $72 \mathrm{~h}$ & [129] \\
\hline \multirow[t]{5}{*}{ Cis-platinum } & LCLs, Raji (BL) & WB & $\mathrm{IE}$ & No & 0 & $1 \mu \mathrm{g} / \mathrm{mL}$ & $5 d$ & [62] \\
\hline & $\begin{array}{c}\text { AGS-EBV (GC), Akata } \\
(\mathrm{BL})\end{array}$ & $\begin{array}{l}\text { WB } \\
\text { FACS }\end{array}$ & $\begin{array}{l}\text { IE, E } \\
\text { BZLF1 }\end{array}$ & $\begin{array}{c}\text { Yes }(+) \\
\text { (only AGS-EBV) }\end{array}$ & + & $1 \mu \mathrm{g} / \mathrm{mL} 10 \mu \mathrm{g} / \mathrm{mL} \mathrm{GCV}$ & $2 d$ & [126] \\
\hline & AGS-EBV (GC) & WB, IF & BMRF1 & No & + & $0.25 \mu \mathrm{g} / \mathrm{mL}$ & $2 d$ & [63] \\
\hline & AGS-Akata & WB & $\mathrm{IE}, \mathrm{E}$ & No & + & $10 \mu \mathrm{mol} / \mathrm{L}$ & $2 d$ & [123] \\
\hline & SNU-719 & WB & $\mathrm{E}$ & Yes $(+)$ & + & $\begin{array}{c}5 \mu \mathrm{g} / \mathrm{mL} \\
2 \mathrm{mg} / \mathrm{mL} \mathrm{GCV}\end{array}$ & $6 d$ & [110] \\
\hline \multirow[t]{3}{*}{ Paclitaxel } & $\begin{array}{c}\text { AGS-EBV (GC), Akata } \\
\text { (BL) }\end{array}$ & $\begin{array}{l}\text { WB } \\
\text { FACS }\end{array}$ & $\begin{array}{l}\text { IE, E } \\
\text { BZLF1 }\end{array}$ & No & + & $10 \mathrm{nmol} / \mathrm{L}$ & $2 d$ & [126] \\
\hline & EBV-Akata (BL) & WB & $\mathrm{IE}, \mathrm{E}$ & No & + & $5 \mu \mathrm{g} / \mathrm{mL}$ & $2 d$ & [123] \\
\hline & SNU-719 (GC) & WB & $E$ & Yes (+) & + & $\begin{array}{c}0.1 \mathrm{nmol} / \mathrm{L} \\
2 \mathrm{mg} / \mathrm{mL} \mathrm{GCV}\end{array}$ & $6 d$ & [110] \\
\hline $\begin{array}{l}\text { Arsenic trioxide } \\
\text { (ATO) }\end{array}$ & $\begin{array}{l}\text { A549-EBVBX1 (lung } \\
\text { carcinoma) }\end{array}$ & $\begin{array}{l}\text { IF, qRT- } \\
\text { PCR }\end{array}$ & $\mathrm{IE}$ & Yes $(+)$ & & $\begin{array}{c}50 \mathrm{nmol} / \mathrm{L} \\
40 \mu \mathrm{mol} / \mathrm{L} \mathrm{GCV}\end{array}$ & $72 \mathrm{~h}(\mathrm{IF}), 24 / 72$ & [131] \\
\hline
\end{tabular}

The column "Result" displays the effect of the drug on lytic induction: an increased (+), inhibited (-) or no significant $(0)$ effect. The column "+GCV" indicates whether the drug described is combined with GCV (Ganciclovir) or not. If a "Yes" is noted in this column; the subsequent symbol shows if the addition of GCV has a positive (+), negative (-) or no effect (0) on the amount of cell killing. WB=Western blot; IF=Immunofluorescence.

Table 3: Summary of chemotherapeutical agents used for EBV lytic induction in cell lines of epithelial and lymphoid origin.

DNA demethylating agent 5-AZA did not increase the expression of the early protein BMRF1 by GCb [63]. Ferreira et al. confirmed data from Richter-Larrea et al. showing that combined treatment of chemotherapy with $\mathrm{NaB}$ resulted in a synergistic effect on apoptosis in $\mathrm{BL}$ cell lines, i.e., etoposide or cisplatin treatment together with $\mathrm{NaB}$ resulted in up-regulation of Bim, Bax, and Caspase-9 activation, while down-regulating Mcl-1 [124,125].

Similar to GCb, 5-fluoruracil (5-FU) is an anti-metabolite that interferes with DNA synthesis. This chemotherapeutic agent triggers lytic induction in gastric cell lines AGS-EBV and SNU-719, but also in the BL cell line Akata $[63,86,110,126]$. Interestingly, Feng et al. did not detect lytic induction by 5-FU in another BL cell line (Raji), nor C666.1 $[62,63]$. On the other hand, they did observe lytic induction in C666.1 when 5-FU was combined with VPA and found that addition of VPA increased the effect of 5-FU in AGS-EBV cells. The addition of antiviral medication was described in two studies, showing that GCV enhanced toxicity of 5-FU in AGS-EBV and SNU-719 [110,126].

Doxorubicin (Dox) is an anthracycline antibiotic with oncolytic effects exerted through topoisomerase II inhibition and disruption of protein-DNA complexes (histone eviction) causing double-strand DNA breaks during mitosis. In a genome-wide gene knockout study, three independent genes were associated with Dox resistance, suggesting that these factors are important for DNA damage induced by Dox [127]. Knock-out of Keap1 or the SWI/SNF complex inhibited formation of
DNA double-strand breaks topoisomerase IIa inhibition, while loss of C9orf82 (CAAP1) enhanced repair of DNA double-strand breaks. Besides generating DNA double-strand breaks, Dox decreases DNA damage response by evicting histone variant $\mathrm{H} 2 \mathrm{AX}$, thereby impairing DNA repair [128]. Only two studies described on the influence of Dox on lytic induction. Both report a strong lytic inducing effect of Dox, either in LCLs or Raji or AGS-EBV cells $[62,129]$. Similar as with GCb, the potency of Dox is increased when it is combined with VPA or GCV, but not when combined with 5-AZA $[62,63]$

Cis-platinum inhibits DNA synthesis by the formation of platinum cross-links in and between DNA strands. Interestingly, this agent seems to be effective in similar cell lines as 5-FUand appears to be a potent lytic inducer in AGS-EBV, SNU-719 and Akata cell lines, but not in Raji and LCLs $[62,63,110,123,126]$. Similar to 5-FU, the effect on EBV reactivation of Cis-platinum is further increased by the addition of VPA (in AGS-EBV) or GCV (in AGS-EBV and SNU-719) $[63,110,126]$.

Paclitaxel (Pacl) is a taxane that disturbs normal microtubule functioning thus interfering with correct chromosomal distribution during mitosis. Feng et al. found that Pacl caused lytic induction in both AGS-EBV (GC) and Akata (BL) cells [123]. Another study confirmed this lytic inducing effect of Pacl in the more natural SNU-719 (GC) cells and showed that, similar to 5-FU, the addition of GCV increased the toxicity of Pacl [110]. 
Arsenic trioxide (ATO) is a chemotherapeutic drug used to treat acute promyelocytic leukemia, and several other hematological and solid cancers. This drug affects multiple cellular pathways, thereby causing induction of apoptosis, inhibition of growth and angiogenesis, and promotion of differentiation [130]. It has been showed that ATO is able to induce EBV lytic cycle in $100 \%$ of treated 549-EBVBX1 (lung adenocarcinoma) cells. Subsequently, these cells became more susceptible to the cell-killing effects of GCV. ATO is able to disrupt promyelocytic leukemia protein nuclear bodies (PML NBs), important for maintenance of EBV latency, thereby activating EBV lytic gene expression and inducing GCV susceptibility in NPC cells [131]. Several clinical trials combining HDACi-s with classical chemotherapeutic and/or target based therapeutics are currently ongoing for solid tumors (including NPC) and haematological malignancies in particular in cutaneous $\mathrm{T}$ cell lymphoma (CTCL), peripheral $\mathrm{T}$ cell lymphoma (PTCL) and Hodgkin lymphoma (HL) [132-134].

\section{Novel Compounds}

Recently, Tikhmyanova et al. have reported the effects of a new class of small molecules with tetrahydrocarboline structure on EBV reactivation in several cell lines with different EBV latency types (including C666.1; Table 4) [135]. 66840 compounds were screened and C09, C50, C53, C60 and C67 were proven to be more potent lytic inducers compared to $\mathrm{NaB}$ or TPA, being effective in nanomolar concentrations and inducing lytic EBV reactivation in nearly $50 \%$ of Mutu I BL cells and over $50 \%$ of LCLs. The mechanism of induction remains to be elucidated, but thusfar these compounds are proven to affect transcription control of viral IE promoters and Zebra transactivator. $\mathrm{NaB}$ caused histone acetylation in Mutu I, MutuLCL 352, but none of newly identified lytic inducers stimulated H3 acetylation. To test whether the newly identified compounds share the mechanism of EBV reactivation with TPA, phosphorylation of p38 MAPK, S6, p90RSK and p53 was checked, and the compounds failed to induce detectable levels of phosphorylation of these targets, suggesting that the mechanisms of EBV activation of these compounds are distinct from $\mathrm{TPA} / \mathrm{NaB}$ mode of action. A similar approach to find new, stronger EBV lytic inducers was used by Choi et al. [136]. They performed a large phenotypic screening on 50240 chemicals, from which two potent compounds were identified; both structurally and biologically distinct from other lytic inducers. The first compound (C7) is structurally similar to iron chelators and the other (E11) is a potent activator of MAPK pathways. The effect of both newly identified lytic inducers was enhanced when combined with the HDAC inhibitor romidepsin.

Reactive oxygen inducing species (ROS) such as hydrogen peroxide $\left(\mathrm{H}_{2} \mathrm{O}_{2}\right)$, Iron (II) sulfate $\left(\mathrm{FeSO}_{4}\right)$ and $\mathrm{N}$-methyl-N'-nitro-Nnitrosoguanidine (MNNG) contribute to the reactivation of EBV lytic cycle $[137,138]$. Hydrogen peroxide is also able to cause lytic induction in AGS-Akata cells [38]. Hagemeier et al. showed that ATM kinase and p53 activation are required for virus reactivation by hydrogen peroxide. On the other hand, they show that EBV-encoded protein kinase (EBV-PK) is not required for ATM activation and subsequently lytic induction by this agent. EBV-PK can activate ATM by upregulating the expression of DNA damage response proteins and TIP60 histone acetyltransferase, thereby promoting lytic induction [139].

TCDD or dioxin (2, 3, 7, 8-tetrachlorodibenzo- $p$-dioxin), a halogenated aromatic hydrocarbon, is a chemical carcinogen. One study shows that this compound is able to reactivate EBV in salivary epithelial cells, but not in BL or B cells [140]. In contrast, dioxin did induce EBV lytic cycle when the BL or B cells were simultaneously treated with TPA.

The nitric oxide synthase (NOS) inhibitor NG-monomethylL-arginine (L-NMMA) caused lytic induction in cell lines derived from gastric and Burkitt lymphoma and enhanced the lytic effect of TPA in gastric cells. This effect was greatly inhibited by the NO donor compounds S-nitroso-penicillamine (SNOP) and S-nitrosoacetylpenicillamine (SNAP) [141,142]. NF- $\kappa B$ is involved in the

\begin{tabular}{|c|c|c|c|c|c|c|c|c|}
\hline Drug & $\begin{array}{c}\text { Cell line } \\
\text { (tumor origin) }\end{array}$ & Assays & Detected proteins & +GCV? & Result & $\begin{array}{l}\text { (Optimal) drug } \\
\text { concentration }\end{array}$ & $\begin{array}{c}\text { (Optimal) } \\
\text { exposure time }\end{array}$ & Ref. \\
\hline $\begin{array}{l}\text { Tetrahydrocarboline } \\
\text { derivatives }\end{array}$ & $\begin{array}{l}\text { Mutu I \& Akata (BL), } \\
\text { C666.1 (NPC), LCLs }\end{array}$ & $\begin{array}{l}\text { WB, RT-PCR } \\
\text { IF (Mutu-I-Hp- } \\
\text { GFP) }\end{array}$ & $\begin{array}{c}\text { BMRF1, BZLF1 } \\
\text { VCA }\end{array}$ & $\begin{array}{l}\text { Yes (+) } \\
\text { (only } \\
\text { Mutu-I) }\end{array}$ & + & $\begin{array}{c}1 \mu \mathrm{mol} / \mathrm{L} \\
10 \mu \mathrm{g} / \mathrm{mL} \mathrm{GCV}\end{array}$ & $\begin{array}{c}72 \text { h (WB), } \\
48 \text { h (RT-PCR) }\end{array}$ & [135] \\
\hline C7, E11 & $\begin{array}{c}\text { AGS-BX1 (GC), } \\
\text { YCCEL1 (GC), } \\
\text { HONE1-EBV (NPC), } \\
\text { C666.1 (NPC, only } \\
\text { C7), SNU719 (GC, } \\
\text { only C7) } \\
\text { AGS-BX1 }\end{array}$ & $\begin{array}{l}\text { WB } \\
\text { IF, flow } \\
\text { cytometry }\end{array}$ & $\begin{array}{c}\mathrm{IE}, \mathrm{E}(\mathrm{E} 11 \text { also L) } \\
\text { Zta }\end{array}$ & $\begin{array}{l}\text { No } \\
\text { No }\end{array}$ & + & $\begin{array}{c}10-20 \mu \mathrm{mol} / \mathrm{L} \\
\\
10 \mu \mathrm{mol} / \mathrm{L} \mathrm{C} 7,20 \\
\mu \mathrm{mol} / \mathrm{L} \mathrm{E} 11\end{array}$ & $\begin{array}{c}\text { 24-96 h (IE, E), } \\
48-96 \text { h (L) } \\
72 \text { h }\end{array}$ & [136] \\
\hline $\mathrm{FeSO}_{4}$ & Raji (BL) & RT-PCR & BZLF1 & No & + & $0.1 \mathrm{mmol} / \mathrm{L}$ & $30 \mathrm{~min}$ & [137] \\
\hline \multirow[t]{3}{*}{$\mathrm{H}_{2} \mathrm{O}_{2}$} & Raji (BL) & RT-PCR & BZLF1 & No & + & $0.2 \mathrm{mmol} / \mathrm{L}$ & $30 \mathrm{~min}$ & [137] \\
\hline & AGS-Akata & WB & $\mathrm{IE}, \mathrm{E}$ & No & + & $300 \mu \mathrm{mol} / \mathrm{L}$ & $2 d$ & [38] \\
\hline & TW01, NA & WB & $\mathrm{IE}, \mathrm{E}$ & No & + & $500 \mu \mathrm{mol} / \mathrm{L}$ & $1 \mathrm{~d}$ & [138] \\
\hline MNNG & $\begin{array}{c}\text { C666.1, NA, HA, } \\
\text { H1299A (NPC) }\end{array}$ & $\begin{array}{c}\text { WB } \\
\text { Flow cytometry } \\
\text { IF }\end{array}$ & $\begin{array}{c}\text { IE, E } \\
\text { EAD } \\
\text { EAD/Zta }\end{array}$ & No & + & $1 \mu \mathrm{g} / \mathrm{mL}$ & $72 \mathrm{~h}$ & [138] \\
\hline $\begin{array}{l}\text { TCDD/ } \\
\text { dioxin }\end{array}$ & $\begin{array}{c}\text { B95-8 (B cell), P3HR1 } \\
\text { (BL) }\end{array}$ & RT-PCR & $\begin{array}{l}\text { BZLF1,BRLF } \\
\text { transcripts }\end{array}$ & No & 0 & $100 \mathrm{nmol} / \mathrm{L}$ & $24 / 48 \mathrm{~h}$ & [140] \\
\hline $\begin{array}{l}\text { TCDD/ dioxin } \\
+ \text { TPA }\end{array}$ & $\begin{array}{c}\text { B-95 (B cell), P3HR1 } \\
\text { (BL) }\end{array}$ & RT-PCR & $\begin{array}{l}\text { BZLF1,BRLF } \\
\text { transcripts }\end{array}$ & No & + & $\begin{array}{l}100 \mathrm{nmol} / \mathrm{L} \text { dioxin, } \\
1 \mathrm{ng} / \mathrm{mL} \text { TPA }\end{array}$ & $24 \mathrm{~h}$ & [140] \\
\hline Parthenolide & Raji (BL) & RT-PCR & IE & Yes (+) & + & $\begin{array}{c}4 \text { or } 6 \mu \mathrm{mol} / \mathrm{L}, 500 \mu \mathrm{g} / \\
\mathrm{mL} \mathrm{GCV}\end{array}$ & $24 \mathrm{~h}$ & {$[87$} \\
\hline SNAP & GT38, GT39 (GC) & WB, NB & IE & No & $\begin{array}{l}\text { - (inhibits } \\
\text { effect of } \\
\text { TPA) }\end{array}$ & $1 \mathrm{mmol} / \mathrm{L}$ & $9 \mathrm{~h}$ & [142] \\
\hline
\end{tabular}




\begin{tabular}{|c|c|c|c|c|c|c|c|c|}
\hline SNOP & Akata (BL) & WB & $\mathrm{IE}, \mathrm{E}$ & No & $\begin{array}{l}\text { - (inhibits } \\
\text { effect of } \\
\text { L-NMMA) }\end{array}$ & $1 \mathrm{mmol} / \mathrm{L}$ & $7 d$ & [141] \\
\hline L-NMMA & Akata, P3HR1 (BL) & $\begin{array}{l}\text { IF } \\
\text { WB }\end{array}$ & $\begin{array}{c}\mathrm{IE} \\
\mathrm{IE}, \mathrm{E}\end{array}$ & No & + & $5 \mathrm{mmol} / \mathrm{L}$ & $7 d$ & [141] \\
\hline L-NMMA & GT38, GT39 (GC) & WB & IE & No & + & $5 \mathrm{mmol} / \mathrm{L}$ & $6 d$ & [142] \\
\hline \multirow[t]{2}{*}{ Bay11-7082 } & $\mathrm{BL}-8(\mathrm{BL})$ & qRT-PCR & IE & No & + & $2.5 \mu \mathrm{mol} / \mathrm{L}$ & $1 \mathrm{~h}$ & [91] \\
\hline & $5-8 \mathrm{~F}(\mathrm{NPC})$ & $\begin{array}{c}\text { WB } \\
\text { Gardella gel }\end{array}$ & $\mathrm{IE}, \mathrm{E}, \mathrm{L}$ & Yes $(+)$ & + & $\begin{array}{l}30 \mu \mathrm{mol} / \mathrm{L} \\
20 \mu \mathrm{mol} / \mathrm{L}\end{array}$ & $24 \mathrm{~h}$ & [146] \\
\hline Z-LLF-CHO & $5-8 \mathrm{~F}(\mathrm{NPC})$ & $\begin{array}{c}\text { WB } \\
\text { Gardella gel }\end{array}$ & $\mathrm{IE}, \mathrm{E}, \mathrm{L}$ & Yes $(+)$ & + & $\begin{array}{c}10 \mu \mathrm{mol} / \mathrm{L} \\
5 \mu \mathrm{mol} / \mathrm{L} \\
100 \mathrm{mg} / \mathrm{ml} \mathrm{GCV}\end{array}$ & $24 \mathrm{~h}$ & [146] \\
\hline $\begin{array}{l}\text { Ca-ionophore } \\
\text { A23187 + TPA }\end{array}$ & B95-8 (LCL) & RT-PCR & $\mathrm{IE}$ & No & + & $\begin{array}{c}1 \mathrm{mmol} / \mathrm{L} \mathrm{Ca}- \\
\text { ionophore, } \\
20 \mathrm{ng} / \mathrm{mL} \text { TPA }\end{array}$ & $12 \mathrm{~h}$ & [152] \\
\hline \multirow[t]{2}{*}{ Azidothymidine (AZT) } & BL-8, BL-5 (BL) & $\begin{array}{c}\text { qRT-PCR } \\
\text { (only BL-8 cells) } \\
\text { WB }\end{array}$ & $\begin{array}{l}\mathrm{IE} \\
\mathrm{E}\end{array}$ & No & + & $10 \mu \mathrm{g} / \mathrm{mL}$ & $\begin{array}{c}16 \mathrm{~h} \text { (real-time } \\
\text { qPCR), } \\
32 \mathrm{~h} \text { (WB) }\end{array}$ & [91] \\
\hline & $\begin{array}{c}\text { BL-8 (BL) } \\
\text { IBL-4 (immunoblastic } \\
\text { lymphoma) }\end{array}$ & $\begin{array}{c}\text { qRT-PCR } \\
\text { IF }\end{array}$ & IE & No & $\begin{array}{l}+(\mathrm{BL}) \\
0(\mathrm{IBL})\end{array}$ & $1.25-2.5 \mu \mathrm{g} / \mathrm{mL}$ & $48 \mathrm{~h}$ & {$[153$} \\
\hline $\begin{array}{c}\text { AZT + hydroxyurea } \\
(\mathrm{HU})\end{array}$ & BL-8, IBL-4 & $\begin{array}{l}\text { qRT-PCR } \\
\text { IF }\end{array}$ & $\mathrm{IE}$ & No & + & $\begin{array}{c}1.25-2.5 \mu \mathrm{g} / \mathrm{mL} \mathrm{AZT} \text {, } \\
25 \mu \mathrm{mol} / \mathrm{L} \mathrm{HU}\end{array}$ & $48 \mathrm{~h}$ & [153] \\
\hline \multirow[t]{2}{*}{$\mathrm{HU}$} & BL-8, IBL-4 & $\begin{array}{l}\text { qRT-PCR } \\
\text { IF }\end{array}$ & IE & No & $\begin{array}{l}+(\mathrm{BL}) \\
0 \text { (IBL) }\end{array}$ & $25 \mu \mathrm{mol} / \mathrm{L}$ & $48 \mathrm{~h}$ & [153] \\
\hline & B95-8 (LCL) & qRT-PCR & & No & - & $1 \mathrm{mmol} / \mathrm{L}$ & $48 \mathrm{~h}$ & [154] \\
\hline $\begin{array}{l}\text { Nocodazole, } \\
\text { colchicine, } \\
\text { vinblastine }\end{array}$ & NA & WB & Zta, EA-D & No & + & $\begin{array}{c}2 \mu \mathrm{g} / \mathrm{ml} \\
0.1 \mu \mathrm{g} / \mathrm{ml} \\
2 \mathrm{~g} / \mathrm{ml}\end{array}$ & $24 \mathrm{~h}$ & [155] \\
\hline Aspirin & B95-8, Raji & WB & $\mathrm{IE}, \mathrm{E}, \mathrm{L}$ & Yes $(+)$ & + & $\begin{array}{c}5 \mathrm{mmol} / \mathrm{L} \\
200 \mu \mathrm{g} / \mathrm{ml} \mathrm{GCV}\end{array}$ & $24 \mathrm{~h}$ & [148] \\
\hline $\begin{array}{l}\text { Hydrocortisone } \\
\text { Dexamethasone }\end{array}$ & $\begin{array}{c}\text { Daudi (BL) } \\
\text { Daudi, C666.1 (NPC), } \\
\text { B98/HR1 (LCL) }\end{array}$ & $\begin{array}{l}\text { RT-PCR } \\
\text { RT-PCR }\end{array}$ & $\begin{array}{l}\text { BZLF1 } \\
\text { BZLF1 }\end{array}$ & $\begin{array}{l}\text { No } \\
\text { No }\end{array}$ & $\begin{array}{l}+ \\
+\end{array}$ & $\begin{array}{c}10 \mu \mathrm{mol} / \mathrm{L} \\
100 \mathrm{nmol} / \mathrm{L}\end{array}$ & $\begin{array}{c}72 \text { h } \\
72 \text { h (Daudi) } 24 \\
\text { h (C666.1, B98/ } \\
\text { HR1) }\end{array}$ & $\begin{array}{l}{[158]} \\
{[156]}\end{array}$ \\
\hline
\end{tabular}

The column "Result" displays the effect of the drug on lytic induction: an increased (+), inhibited (-) or no significant $(0)$ effect. The column "+GCV" indicates whether the drug described is combined with GCV (Ganciclovir) or not. If a "Yes" is noted in this column; the subsequent symbol shows if the addition of GCV has a positive (+), negative (-) or no effect $(0)$ on the amount of cell killing. WB=Western blot; IF=Immunofluorescence.

Table 4: Effects on EBV lytic induction in cell lines of epithelial and lymphoid origin by novel compounds.

modulation of EBV lytic cycle. The EBV latency oncogenic protein LMP1 inhibits virus reactivation via NF- $\mathrm{KB}$ activation [18-20,143-145]. Liu et al. showed that NF- $\kappa B$ inhibitors Bay11-7082 and Z-LLF-CHO were able to reactivate EBV in NPC cells [146]. Besides, they showed that GCV further amplified the cytotoxicity of these compounds. Bay11-7082 also caused lytic induction in a BL cell line [91].

Aspirin is a non-steroidal anti-inflammatory drug (NSAID) with NF-kB inhibiting properties [147]. Liu et al. confirmed that aspirin depleted NF-kB activity in a dose- and time-dependent manner and furthermore showed that aspirin reactivated EBV in B95-8 (EBVpositive marmoset B-lymphoblastoid cell line) and Raji BL-cells [148]. When GCV was used in combination with aspirin, a synergistic effect on cytotoxicity was observed.

Parthenolide is a sesquiterpene lactone found in medicinal plants. It has antitumor properties including inhibition of DNA synthesis, inhibition of cell proliferation and inhibition of NF- $\mathrm{KB}[149,150]$. Furthermore, Li et al. showed that Parthenolide caused lytic induction in Raji cells. It cytotoxic effect was amplified by the addition of GCV [87].

Faggioni et al. showed that calcium ionophores caused EBV antigens expression in LCLs [151]. This effect was enhanced when protein kinase $C$ was activated suggesting that protein kinase $C$ is required for lytic induction [151]. A more recent study described that the same calcium ionophore, in combination with TPA, is able to induce EBV lytic cycle in B95-8 cells [152].
Zidovudine or azidothymidine (AZT) is a nucleoside analog reverse-transcriptase inhibitor (NRTI), an antiviral used to treat HIV infection. It is also an effective lytic inducer in BL cells, but not in immunoblastic lymphoma (IBL) cells $[91,153]$. On the other hand, in both cell lines the combination of AZT with the cytostatic agent hydroxyurea (HU) resulted in synergistic EBV reactivation. Furthermore, Bayraktar et al. observed promising results of AZT based chemotherapeutic treatment in patients with aggressive EBV-positive non-Hodgkin lymphoma. HU alone was, similar to AZT, only effective in BL cells but not in IBL cells [153]. Another study even shows a suppression of lytic genes expression after HU-treatment in B95-8 cells [154].

Nocodazole is an anti-neoplastic agent that interferes with microtubule polymerization and is able to cause lytic induction in NPC cells. Two other microtubule inhibitors, Colchicine and Vinblastine, also show induction of ZEBRA and EA-D antigen expression. In contrast, Paclitaxel, which inhibits microtubule depolymerization, and cytochalasin $\mathrm{D}$, which blocks actin polymerization, did not show any lytic induction in these cells. These findings suggest that microtubule depolymerization induces EBV lytic cycle. Furthermore, this study showed that EBV reactivation by Nocodazole depends on PKC and the downstream p38 MAPK and JNK pathways [155].

Yang et al. reported BZLF1-mediated reactivation of EBV by glucocorticoids (hydrocortisone and dexamethasone) in Daudi (BL cells naturally expressing glucocorticoid receptors) and GR transfected NPC cells (C666.1) but not in marmoset lymphoblastoid 
B95-8 cell line [156]. Generally, physical and mental stress conditions are considered to induce EBV replication [157]. Daibata et al. described that combination therapy of dexamethasone with rituximab potentates EBV positive lymphoma for GCV-mediated antiviral effects in vitro and in vivo [158].

Icaritin is a compound with anti-tumor properties, derived from traditional Chinese herbal medicine Epimedium. It was shown to induce lytic cytotoxicity in EBV-positive extranodal NK/T-cell lymphoma (ENKL) cell lines by activation of pro-apoptotic pathways and this effect was amplified by the addition of GCV. The antiproliferative and pro-apoptotic effects are likely mediated by inhibition of Stat 3 and Akt pathways and LMP1 downregulation [159].

\section{Host cell factors influencing susceptibility to EBV lytic reactivation and interference of lytic inducers on signaling pathways}

Complex regulation of cellular and viral genomes including epigenetic modifications of histones and DNA, chromatin organization and transcription factors binding determine EBV gene expression programs and latency types in normal and cancer cells [160,161]. Recently viral microRNAs (miRNAs) have been reported to control IE genes and directly suppress lytic induction [162,163]. EBV latency program(s) are tightly regulated by epigenetic control mechanisms $[112,115]$. EBV lytic induction by chemicals is a cell type specific and generally achieved easier in lymphoma than carcinoma cell lines. Viral latency gene products can also affect (epigenetic) regulation of the host genome. Latent membrane protein 1 (LMP1) is the main EBV oncogene, inhibiting apoptosis and stimulating proliferation, by constitutive activating NF-kB, which is important for maintenance of viral latency $[164,165]$. On the other hand, canonical NF-kB activation is crucial for regulation of LMP1 [166]. Besides NF-kB, the major cellular signaling pathways triggered by LMP1 (in NPC cells) are AP-1 (JUN, FOS, ATF, MAF), JAK/STAT and PKC [167]. LMP1 C-terminus interaction with JAK3 activates STAT signaling pathway in B cells, which is in line with well-known LMP1 anti-apoptotic properties [21]. Recently Hill et al. reported that lower STAT3 levels promote susceptibility to lytic inducing agents [168]. Sorted HH514-16 latent BL cells (latency type I BL) appeared to have elevated levels of KRABZFP family (transcriptional repressors recruiting histone deacetylases) and histone methyltransferase transcripts compared to untreated or lytic cells. Also low STAT3 levels correlated with high lytic gene expression in circulating B cells in early infected IM patients. On the other hand, high levels of STAT3 in latently infected epithelial cells upregulate LMP1, which is known to block the induction of the lytic cycle $[143,169]$.

The expression of EBV transactivator BZLF1 is stringently controlled. BZLF1 promoter (Zp) generally exhibits low basal activity. Stimulation by chemical (TPA) and biological inducers is mediated via transcriptional factors such as MEF-2D and SP1/3 [170]. Myocyte enhancer binding factor 2 (MEF-2) family proteins are important host factors for reactivation of EBV from latency $[66,171]$. When bound to class II HDACs, MEF-2 transcriptional activity is repressed [172-174]. Activation is mediated by several kinases such as ERK5 and CaMK, and transcriptional activity (by disrupting MEF2/HDAC complexes) is allowing the recruitment of histone acetyl-transferases (HATs) [173]. MEF-2D is one of the main (positive) regulators of BZLF1 transcription and phosphorylation by ERK5-kinase enhances its ability to positively regulate the transcription of $\mathrm{Zp}$. In latency, MEF-2D binds to ZI element and interacts with class II HDACi-s, suppressing the Zp transcription [175]. Activation of the host gene egrl is essential for the lytic replication of EBV as Zta interacts with methylated ZRE in the promoter of egr1 [176].

The activation of the lytic cycle by TPA is attributed to activation of the ERK signal transduction pathway $[103,177]$. Knowing that also VPA is shown to activate the ERK pathway, it is possible VPA might stimulate EBV lytic gene expression via ERK, especially when combined with chemo agents [178].

In BL (Raji) cells, HDACis (sodium butyrate, $\mathrm{NaB}$ ) are targeting PI3K/Akt pathway and upregulating miR-143, miR-145 and miR-101, preventing cell growth [179].

Daigle et al. compared different HDACi-s for their EBV lytic induction properties and VPA was shown to selectively up-regulate certain cellular genes (including MEF-2D, YY1 and ZEB1) that could repress the EBV lytic cycle [105]. The authors demonstrated that VPA is able to antagonize the capacity of other HDACi-s to activate EBV lytic cycle in lymphoid cells. Murata et al. reported that expression of KLF4 a member of the SP1/KLF family and MEF-2B enhanced Zp activity and demonstrated that MEF-2 enhances the expression of not only BZLF1 but also BRLF1 gene by binding to Zp [180]. Liu et al. have demonstrated involvement of MEF-2D in the activation of the $\mathrm{Zp}$, but in the reporter system used by Murata et al. MEF-2D did not enhance Zp transcriptional activity [170]. HIF-2 $\alpha$ was also identified as a strong inducer of the $\mathrm{Zp}$, linking oxygen deprivation to virus lytic induction [180].

Promoters of butyrate-responsive genes have butyrate response elements, and the action of butyrate is often mediated through Sp1/Sp3. These Sp1/Sp3-binding sites (ZIA, ZIC and ZID domains; see Figure 2) are responsive elements critical for TPA-induced $\mathrm{Zp}$ activation [41]. Inhibition of Sp1/Sp3-associated HDAC-activity leads to histone hyperacetylation and transcriptional activation of the cell cycle kinase inhibitor $\mathrm{p} 21^{\mathrm{CIP}-1}$ gene, restricted Cdk-2 activity and cell cycle arrest. Depending of the cell background, the non-proliferating cells may enter differentiation or apoptotic pathways $[83,181]$.

In experiments with $\mathrm{TPA} / \mathrm{NaB}$ mediated lytic induction in epithelial cells, Huang et al. showed that Zebra expression is regulated, among others by CCAAT-enhancer binding proteins (C/EBP; regulators of differentiation) and proposed model of C/EBP activity in epithelial cells, suggesting that limited expression of C/EBP proteins in epithelial cells (AGS-BX1) may contribute to the tendency to exhibit constitutive low-level $\mathrm{Zp}$ activity [182]. Interaction of C/EBP with Zebra is facilitating G1 cell cycle arrest and accumulation of $\mathrm{p} 21^{\mathrm{CIP}-1}$ during EBV lytic cycle [42].

ZEB1 (zinc finger E-box-binding protein 1) was identified as the major cellular factor in B-lymphocytes which can repress BZLF1 gene expression by directly binding to its promoter, $\mathrm{Zp}$ [183]. Yu et al. further confirmed that ZEB1 plays a central role in negatively regulating the latent-lytic switch in EBV-infected epithelial and B cells (Figure 2), and suggested to use agents that lower the repressor activity of ZEB1 to treat EBV-positive malignancies [184]. Studies of Ellis et al. suggested that either ZEB1 or ZEB2/SIP1 may play a central role in regulating EBVreactivation in a cell type specific manner, and proposed a model of BZLF1 gene expression by both ZEBs [185]. ZEB1 and ZEB2 levels vary in different EBV-infected cell lines and both bind to ZV element of Zp. Authors also found evidence that EBV latency-lytic switch is positively regulated by cellular microRNAs (200b and 429) and suggested a role in differential ZEB1 and ZEB2 expression [186]. ZEB1, ZEB2/SIP1 are negative regulators of $\mathrm{Zp}$. Sp1 binds to and activates $\mathrm{Zp}$, counteracting repressing effects of ZEBs. Interestingly, AGS cells contain little or no ZEB1 (and high c-JUN and ATF-2) which may explain why among transformed epithelial cell lines, AGS cells are uniquely susceptible to maintaining EBV infection in a highly lytic form [187]. Recently Zhao et al. reported that ZEB1 is a key mediator in lytic induction of EBVpositive gastric cancer cell lines, therefore considered as a potential 
therapeutically target [188].

The protein kinase $\mathrm{C}$ ( $\mathrm{PKC})$ pathway has been considered to be essential for rendering latent EBV into the lytic cycle by antiIg treatment and a PKC agonist TPA [103,189]. Lytic induction by HDACi-s is facilitated by a PKC-independent mechanism [104]. The essential role of $\mathrm{PKC}$ delta in $\mathrm{HDACi}$-induced $\mathrm{EBV}$ reactivation in NPC cells (by TSA/NaB) was deciphered by Lee at al. [190].

Chang et al. found that post-translational modification of Rta by SUMO-1 in P3HR1 cells increases Rta transactivation activity upon lytic induction by $\mathrm{TPA} / \mathrm{NaB}$ or TSA and identified Ubc 9 and PIAS (enzymes involved in sumoylation) as binding partners of Rta by yeast two-hybrid screen [191]. The same authors reported that Sp1-MCAF1Rta complex is crucial in transcription regulation of Rta and takes part in activation of EBV lytic cycle (in P3HR1 cells treated with TPA and sodium butyrate) [192]. TPA with NaB activates PKC theta-p38 MAPK axis in EBV infected B cells, that promotes the viral lytic cycle and cell survival and dephosphorylates AKT, balancing cell life and cell death [193].

\section{DNA damage response (DDR) and EBV lytic replication cycle}

Previous studies have shown that lytic reactivation of EBV in latently-infected cells induces ATM-dependent DNA damage response (DDR). Suppression of ATM inhibits replication of viral DNA. During the lytic EBV replication cycle the ATM-dependent DNA damage checkpoint signaling, including phosphorylated ATM, H2AX, Chk2 and $\mathrm{p} 53$ are activated $[194,195]$. BPLF1 is a structural tegument protein playing a role in DDR as trans-activator of viral immediate-early genes [196]. This protein is sufficient to induce ATM-dependent pathway through stabilization of Cdt1 and induction of EBV lytic cascade in response to activation of BZLF1, thereby, causing a DNA hyperreplication that in turn activates the DDR [197]. During the EBV lytic induction the key lytic switch protein BZLF1 interacts with p53 and inhibits its function through multiple mechanisms, which results in prevention of the cell cycle arrest and apoptosis, along with facilitating the viral DNA replication through engaging the 53BP1, a DNA repair protein $[198,199]$. A recent study indicates that Zta expression alone is sufficient to trigger ATM-phosphorylation and DDR-pathway activation independent of EBV-DNA replication requiring Zta-DNA complex formation co-associating with $\mathrm{HP} 1 \beta$, a heterochromatin binding protein, thus creating a nuclear microenvironment for lytic gene expression and viral DNA replication [200].

Promyelocytic leukemia protein nuclear bodies (PML NBs) are proteinaceous structures present in the nuclei of cells. They are able to affect several nuclear processes, such as regulating gene transcription. Bell et al. observed a connection between EBV replication domains and PML bodies, indicating that replication of EBV occurs in association with PML [201]. EBNA1 is known to affect proper assembly of PML bodies and dysfunctional PML bodies affect DNA damage repair and trigger lytic replication [47]. Furthermore, other researchers discovered that LMP1 (important for the maintenance of EBV latency) increases the IF intensity of PML bodies [131]. This suggests that LMP1 is maintaining EBV latency by stabilizing these bodies. Subsequently to initiate virus replication, IE ZEBRA protein is able to disrupt the PML bodies, implying that these NBs are important to keep EBV in the latent state [202]. Moreover, Sides et al. observed that arsenic trioxide can interrupt these nuclear bodies, inducing EBV lytic phase and additionally accomplishing GCV susceptibility in nasopharyngeal carcinoma cells [131].

Several studies revealed the role of DNA-damaging agents, including chemotherapeutics, some HDACi-s and radiation, in reactivation of
EBV genome initiated by ATM-pathway signaling [123,203,204]. In the absence of DNA damage, ATM kinase can also be activated in response to reactive oxygen species (ROS). ATM activity contributes to the induction of EBV lytic gene expression $[123,205]$. The mechanisms by which chemoagents and HDACi-s activate the lytic induction of EBV are not fully understood. It is likely that activation of p53, which is a downstream target of ATM and requires ATM phosphorylation at ser-1981 in response to different stimuli, is an essential factor by which DNA-damaging agents induce EBV reactivation [38,206,207].

Tumor suppressor p53 plays a central part in DNA damage responses (DDR) mediating cell cycle arrest/apoptosis. The regulation of $\mathrm{Zp}$ activity by $\mathrm{p} 53$ is achieved through interaction with $\mathrm{Sp} 1$ (recruitment to Sp1-binding site located in the ZID domain of Zp) and new studies showed involvement of PKC delta $[207,208]$. EBV inhibits p53 by facilitating its degradation via ubiquitin-proteasome pathway [209]. The cell cycle regulator p53 is required for HDACi-mediated lytic reactivation both in EBV-positive NPC cell lines and lymphoblastoid B cell lines, which further supports the critical role of p53 and ATM in EBV reactivation $[123,207]$. The $\mathrm{p} 53$ has been shown to induce the lytic gene expression in many cell lines by different mechanisms, including the overexpression of BRRF1 and BRLF1, activating BZLF1 promoter by forming a complex with SP1, which binds and activates BZLF1 promoter, and inhibiting two potent repressors of BZLF1, ZEB1 and ZEB2 [38,185,207]. BGLF4 phosphorylates and activates TIP60 and acetylation of ATM by TIP60, which is a HAT, contributes to ATM activation [139]. Several EBV latent proteins, such as EBNA1, EBNA3C, LMP1, and LMP2A, have been shown to inhibit the DDR, with LMP1 and LMP2A in particular inhibiting the ATM kinase activity [210,211]. Besides the p53-dependent activation of lytic-cycle by ATM, this kinase is also known to enhance the activation of BZLF1 promoter by a different set of cellular and viral proteins. Since ATM inhibition was shown to block EBV reactivation in p53-negative cells, it is proposed that ATM plays a significant role in promoting lytic EBV reactivation via both p53-dependent and p53-independent pathways [123]. It has been speculated that multiple different targets of ATM, such as $\mathrm{H} 2 \mathrm{AX}$ and Chk2, are involved in EBV viral gene expression, since ATM phosphorylates over 700 cellular proteins. However, the exact mechanism of this is not yet completely understood [212]. In recent study of Hau et al. ATM-dependent DDR involvement in EBV lytic reactivation in nasopharyngeal epithelial cells was investigated ATMmediated activation of Sp1 (Serine - 101 residue phosphorylation) was identified as an essential process in viral DNA replication [208].

\section{Conclusions}

EBV has evolved a complex interaction with its human host, resulting in a lifelong balanced latency where the virus limits host damage by staying undercover in memory B-cells and replicating only in mucosal lymphoid tissues and epithelia. Although generally harmless, under specific conditions EBV plays a causal role as (co-) factor in triggering defined malignancies, all harboring EBV in a state of latency, without overt lytic replication. In these tumors the oncogenic character of EBV latency proteins is clearly visible and contributes to the malignant process, stimulating cell growth and metastasis, as well as apoptosis resistance and immune evasion [1,6,15-17]. Reactivating EBV from latency into early-stage lytic replication induces expression of viral genes that can be targeted by immunological and antiviral strategies to eliminate virus carrying tumor cells $[4,60,62,64,69]$.

Over the years, significant progress has been made towards identifying and testing novel highly specific and efficient agents (drugs) for targeted reactivation of the latent viral genome and inducing cytocidal effects in various EBV-driven tumor cells. This strategy is 
Citation: Novalić Z, van Rossen TM, Greijer AE, Middeldorp JM (2016) Agents and Approaches for Lytic Induction Therapy of Epstein-Barr Virus Associated Malignancies. Med chem (Los Angeles) 6: 449-466. doi:10.4172/2161-0444.1000384

referred to as viral cytolytic virus activation (CLVA) therapy which has recently entered the clinical testing stage in Phase-I/-II trials $[64,65,68,107]$. One of the complications we faced when comparing the various lytic inducers, was the heterogeneity of research models and methods used. To begin with, the different studies used multi-variable drug concentrations and treatment durations and many compounds were tested in different cell lines, often derived from different tissues (i.e., gastric carcinoma, nasopharyngeal carcinoma and lymphoma cell lines). Furthermore, effectiveness of lytic inducers was demonstrated by different techniques (presented in Tables 1-4) including detection of different EBV (immediate) early or late lytic proteins and mRNA expression, as well as functional characteristics such as apoptosis induction and sensitivity to antiviral treatment. Active compounds were classified based on their mechanism(s) of action and efficiency in different tumor cell systems. Some of the major signalling pathways are highlighted in response to different stimuli and susceptibility to EBV reactivation in different cell backgrounds is discussed. The antiviral nucleoside analogue (val)Ganciclovir combined with lytic EBV inducers is promising for treating EBV-positive cancers creating DNA chain termination in dividing cells expressing the early lytic stage TK and PK proteins. New agents and combinations remain to be tested in (pre-) clinical situations. A particularly interesting category are novel HDACI's [213]. Recently, novel compounds were identified from screening a library of small organic compounds and 2 of them demonstrated to be especially promising in inducing rapid EBV reactivation from latency in GC and NPC cells [136]. Relevant "targetable" pathways in EBV-associated GC tumors and nasopharyngeal carcinoma, including overviews of (current) clinical trials were recently summarized $[69,70,214]$. Currently efforts are ongoing to identify specific natural edible fito-compounds and derivatives potent enough to induce EBV reactivation [159]. Additional work is necessary to study the effect of the lytic inducers in a more uniform way and to bring consensus in crucial pathways leading to virus reactivation in different (tumor) cell backgrounds. Recent CLVA trials show promising results in patients with either EBV-driven lymphoma or carcinoma [65,68,107]. This virus-targeted therapy might initiate a general treatment approach for various EBV-associated malignancies.

\section{References}

1. Young LS, Rickinson AB (2004) Epstein-Barr virus: 40 years on. Nat Rev Cancer 4: 757-768.

2. Odumade OA, Hogquist KA, Balfour HH Jr (2011) Progress and problems in understanding and managing primary Epstein-Barr virus infections. Clin Microbiol Rev 24: 193-209.

3. Steven NM (1997) Epstein-Barr virus latent infection in vivo. Rev Med Virol 7: 97-106.

4. Hislop AD (2015) Early virological and immunological events in Epstein-Barr virus infection. Curr Opin Virol 15: 75-79.

5. Taylor GS, Long HM, Brooks JM, Rickinson AB, Hislop AD (2015) The immunology of Epstein-Barr virus-induced disease. Annu Rev Immunol 33: 787-821.

6. Thorley-Lawson DA, Gross A (2004) Persistence of the Epstein-Barr virus and the origins of associated lymphomas. N Engl J Med 350: 1328-1337.

7. Tugizov SM, Berline JW, Palefsky JM (2003) Epstein-Barr virus infection of polarized tongue and nasopharyngeal epithelial cells. Nat Med 9: 307-314

8. Borza CM, Hutt-Fletcher LM (2002) Alternate replication in B cells and epithelial cells switches tropism of Epstein-Barr virus. Nat Med 8: 594-599.

9. Hawkins JB, Delgado-Eckert E, Thorley-Lawson DA, Shapiro M (2013) The cycle of EBV infection explains persistence, the sizes of the infected cell populations and which come under CTL regulation. PLoS Pathog 9: e1003685.

10. Hadinoto V, Shapiro M, Sun CC, Thorley-Lawson DA (2009) The dynamics of EBV shedding implicate a central role for epithelial cells in amplifying viral output. PLoS Pathog 5: e1000496.
11. Pegtel DM, Middeldorp J, Thorley-Lawson DA (2004) Epstein-Barr virus infection in ex vivo tonsil epithelial cell cultures of asymptomatic carriers. J Virol 78: 12613-12624.

12. Hudnall SD, Ge Y, Wei L, Yang NP, Wang HQ, et al. (2005) Distribution and phenotype of Epstein-Barr virus-infected cells in human pharyngeal tonsils. Mod Pathol 18: 519-527.

13. Greenspan JS, Greenspan D, Webster-Cyriaque J (2016) Hairy leukoplakia; lessons learned: 30-plus years. Oral Dis 22 Suppl 1: 120-127.

14. Tse E, Kwong YL (2015) Epstein Barr virus-associated lymphoproliferative diseases: the virus as a therapeutic target. Exp Mol Med 47: e136.

15. Middeldorp JM, Brink AA, van den Brule AJ, Meijer CJ (2003) Pathogenic roles for Epstein-Barr virus (EBV) gene products in EBV-associated proliferative disorders. Crit Rev Oncol Hematol 45: 1-36.

16. Kang MS, Kieff E (2015) Epstein-Barr virus latent genes. Exp Mol Med 47: e131.

17. Tsao SW, Tsang CM, To KF, Lo KW (2015) The role of Epstein-Barr virus in epithelial malignancies. J Pathol 235: 323-333.

18. Kieser A, Sterz KR (2015) The Latent Membrane Protein 1 (LMP1). Curr Top Microbiol Immunol 391: 119-149.

19. Devergne O, Hatzivassiliou E, Izumi KM, Kaye KM, Kleijnen MF, et al (1996) Association of TRAF1, TRAF2, and TRAF3 with an Epstein-Barr virus LMP1 domain important for B-lymphocyte transformation: role in NF-kappaB activation. Mol Cell Biol 16: 7098-7108.

20. Uchida J, Yasui T, Takaoka-Shichijo Y, Muraoka M, Kulwichit W, et al (1999) Mimicry of CD40 signals by Epstein-Barr virus LMP1 in B lymphocyte responses. Science 286: 300-303.

21. Gires O, Kohlhuber F, Kilger E, Baumann M, Kieser A, et al. (1999) Latent membrane protein 1 of Epstein-Barr virus interacts with JAK3 and activates STAT proteins. EMBO J 18: 3064-3073.

22. Dawson CW, Tramountanis G, Eliopoulos AG, Young LS (2003) Epstein-Bar virus latent membrane protein 1 (LMP1) activates the phosphatidylinositol 3-kinase/Akt pathway to promote cell survival and induce actin filament remodeling. J. Biol. Chem 278: 3694-3704.

23. Peng $H$, Chen $Y$, Gong $P$, et al. (2016) Higher methylation intensity induced by EBV LMP1 via NF-1 $1^{\circ} \mathrm{B} / \mathrm{DNMT} 3 \mathrm{~b}$ signaling contributes to silencing of PTEN gene. Oncotarget.

24. Verweij FJ, van Eijndhoven MA, Hopmans ES, Vendrig T, Wurdinger T, et al (2011) LMP1 association with CD63 in endosomes and secretion via exosomes limits constitutive NF-kappaB activation. EMBO J. 30: 2115-2129.

25. Cen O, Longnecker R (2015) Latent Membrane Protein 2 (LMP2). Curr Top Microbiol Immunol 391: 151-180.

26. Anderson LJ, Longnecker R (2008) EBV LMP2A provides a surrogate pre-B cell receptor signal through constitutive activation of the ERK/MAPK pathway. J Gen Virol 89: 1563-1568.

27. Scholle F, Bendt KM, Raab-Traub N (2000) Epstein-Barr virus LMP2A transforms epithelial cells, inhibits cell differentiation, and activates Akt. J Virol 74: 10681-10689.

28. Murata T, Tsurumi T (2014) Switching of EBV cycles between latent and lytic states. Rev Med Virol 24: 142-153.

29. Bhende PM, Seaman WT, Delecluse HJ, Kenney SC (2004) The EBV lytic switch protein, $Z$, preferentially binds to and activates the methylated viral genome. Nat Genet 36: 1099-1104.

30. Bergbauer M, Kalla M, Schmeinck A, Göbel C, Rothbauer U, et al. (2010) CpGmethylation regulates a class of Epstein-Barr virus promoters. PLoS Pathog 6: e1001114.

31. Kalla M, Schmeinck A, Bergbauer M, Pich D, Hammerschmidt W (2010) AP-1 homolog BZLF1 of Epstein-Barr virus has two essential functions dependent on the epigenetic state of the viral genome. Proc Natl Acad Sci USA 107: 850-855

32. Kalla M, Göbel C, Hammerschmidt W (2012) The lytic phase of epstein-barr virus requires a viral genome with 5-methylcytosine residues in CpG sites. J Virol 86: 447-458.

33. Petosa C, Morand P, Baudin F, Moulin M, Artero JB, et al. (2006) Structural basis of lytic cycle activation by the Epstein-Barr virus ZEBRA protein. Mol Cell 21: 565-572.

34. Sinclair AJ (2013) Epigenetic control of Epstein-Barr virus transcription relevance to viral life cycle? Front Genet 4: 161. 
Citation: Novalić Z, van Rossen TM, Greijer AE, Middeldorp JM (2016) Agents and Approaches for Lytic Induction Therapy of Epstein-Barr Virus Associated Malignancies. Med chem (Los Angeles) 6: 449-466. doi:10.4172/2161-0444.1000384

35. Israel B, Kenney SC (2011) EBV Iytic infection. In Epstein-Barr virus; Robertson ES Caister Academic Press: Philadelphia, PA 571-611.

36. Hong GK, Delecluse HJ, Gruffat H, Morrison TE, Feng WH, et al. (2004) The BRRF1 early gene of Epstein-Barr virus encodes a transcription factor that enhances induction of lytic infection by BRLF1. J Virol 78: 4983-4992.

37. Dickerson SJ, Xing Y, Robinson AR, Seaman WT, Gruffat H, et al. (2009) Methylation-dependent binding of the epstein-barr virus BZLF1 protein to viral promoters. PLoS Pathog 5: e1000356.

38. Hagemeier SR, Barlow EA, Kleman AA, Kenney SC (2011) The EpsteinBarr virus BRRF1 protein, $\mathrm{Na}$, induces lytic infection in a TRAF2- and p53dependent manner. J Virol 85: 4318-4329.

39. Juillard F, Bazot Q, Mure F, Tafforeau L, Macri C, et al. (2012) Epstein-Barr virus protein $\mathrm{EB} 2$ stimulates cytoplasmic $\mathrm{mRNA}$ accumulation by counteracting the deleterious effects of SRp20 on viral mRNAs. Nucleic Acids Res 40: 6834-6849.

40. Lu CC, Jeng YY, Tsai CH, Liu MY, Yeh SW, et al. (2006) Genome-wide transcription program and expression of the Rta responsive gene of EpsteinBarr virus. Virology 345: 358-372.

41. Kieff E, Rickinson AB (2007) Epstein-Barr virus and its replication. In: Fields Virology. 5th edn. Knipe DM, et al. Lippincott, Williams \& Wilkins: Philadelphia, PA, USA, pp: 2603-2654.

42. Wu FY, Chen H, Wang SE, ApRhys CM, Liao G, et al. (2003) CCAAT/enhancer binding protein alpha interacts with ZTA and mediates ZTA-induced p21(CIP-1) accumulation and G(1) cell cycle arrest during the Epstein-Barr virus lytic cycle. J. Virol 77: 1481-1500

43. Davies ML, Xu S, Lyons-Weiler J, Rosendorff A, Webber SA, et al. (2010) Cellular factors associated with latency and spontaneous Epstein-Barr virus reactivation in B-lymphoblastoid cell lines. Virology 400: 53-67.

44. Reusch JA, Nawandar DM, Wright KL, Kenney SC, Mertz JE (2015) Cellular differentiation regulator BLIMP1 induces Epstein-Barr virus lytic reactivation in epithelial and $B$ cells by activating transcription from both the $R$ and $Z$ promoters. J. Virol 89: 1731-1743.

45. Nawandar DM, Wang A, Makielski K, Lee D, Ma S, et al. (2015) DifferentiationDependent KLF4 Expression Promotes Lytic Epstein-Barr Virus Infection in Epithelial Cells. PLoS. Pathog 11: e1005195.

46. Wille CK, Nawandar DM, Henning AN, Ma S, Oetting KM, et al. (2015) 5-hydroxymethylation of the EBV genome regulates the latent to lytic switch. Proc Natl Acad Sci USA 112: E7257-7265.

47. Sivachandran N, Wang X, Frappier L (2012) Functions of the Epstein-Barr virus EBNA1 protein in viral reactivation and lytic infection. J Virol 86: 6146-6158.

48. Ji MF, Wang DK, Yu YL, Guo YQ, Liang JS, et al. (2007) Sustained elevation of Epstein-Barr virus antibody levels preceding clinical onset of nasopharyngeal carcinoma. Br. J. Cancer 96: 623-630.

49. Cao SM, Liu Z, Jia WH, Huang QH, Liu Q, et al. (2011) Fluctuations of epsteinbarr virus serological antibodies and risk for nasopharyngeal carcinoma: prospective screening study with a 20-year follow-up. PLoS One 6: e19100.

50. Liu Y, Huang Q, Liu W, Liu Q, Jia W, et al. (2012) Establishment of VCA and EBNA1 IgA-based combination by enzyme-linked immunosorbent assay as preferred screening method for nasopharyngeal carcinoma: a two-stage design with a preliminary performance study and a mass screening in southern China. Int. J. Cancer 131: 406-416.

51. Yu MC, Huang TB, Henderson BE (1989) Diet and nasopharyngeal carcinoma: a case-control study in Guangzhou, China. Int J Cancer 43: 1077-1082.

52. Jia WH, Luo XY, Feng BJ, Ruan HL, Bei JX, et al. (2010) Traditional Cantonese diet and nasopharyngeal carcinoma risk: a large-scale case-control study in Guangdong, China. BMC Cancer 10: 446

53. Huang SY, Fang CY, Tsai CH, Chang Y, Takada K, et al. (2010) N-methyl-N'-nitro$\mathrm{N}$-nitrosoguanidine induces and cooperates with 12-O-tetradecanoylphorbol1,3-acetate/sodium butyrate to enhance Epstein-Barr virus reactivation and genome instability in nasopharyngeal carcinoma cells. Chem. Biol. Interact 188: 623-634.

54. Xue WQ, Qin HD, Ruan HL, Shugart YY, Jia WH (2013) Quantitative association of tobacco smoking with the risk of nasopharyngeal carcinoma: a comprehensive meta-analysis of studies conducted between 1979 and 2011. Am J Epidemiol 178: 325-338.

55. Fang CY, Huang SY, Wu CC, Hsu HY, Chou SP, et al. (2012) The synergistic effect of chemical carcinogens enhances Epstein-Barr virus reactivation and tumor progression of nasopharyngeal carcinoma cells. PLoS. One 7: e44810.

56. Feng BJ, Jalbout M, Ayoub WB, Khyatti M, Dahmoul S, et al. (2007) Dietary risk factors for nasopharyngeal carcinoma in Maghrebian countries. Int. J. Cancer 12: $1550-1555$.

57. Westphal EM, Blackstock W, Feng W, Israel B, Kenney SC (2000) Activation of lytic Epstein-Barr virus (EBV) infection by radiation and sodium butyrate in vitro and in vivo: a potential method for treating EBV-positive malignancies. Cancer Res 60: 5781-5788.

58. Ghosh SK, Perrine SP, Williams RM, Faller DV, et al. (2012) Histone deacetylase inhibitors are potent inducers of gene expression in latent EBV and sensitize lymphoma cells to nucleoside antiviral agents. Blood 119: 1008-1017.

59. Moolten FL (1986) Tumor chemosensitivity conferred by inserted herpes thymidine kinase genes: paradigm for a prospective cancer control strategy. Cancer Res 46: 5276-5281.

60. Gutiérrez MI, Judde JG, Magrath IT, Bhatia KG (1996) Switching viral latency to viral lysis: a novel therapeutic approach for Epstein-Barr virus-associated neoplasia. Cancer Res 56: 969-972.

61. Meng Q, Hagemeier SR, Fingeroth JD, Gershburg E, Pagano JS, et al. (2010) The Epstein-Barr virus (EBV)-encoded protein kinase, EBV-PK, but not the thymidine kinase (EBV-TK), is required for ganciclovir and acyclovir inhibition of lytic viral production. J Virol 84: 4534-4542.

62. Feng WH, Hong G, Delecluse HJ, Kenney SC (2004) Lytic induction therapy for Epstein-Barr virus-positive B-cell lymphomas. J Virol 78: 1893-1902.

63. Feng WH, Kenney SC (2006) Valproic acid enhances the efficacy of chemotherapy in EBV-positive tumors by increasing lytic viral gene expression. Cancer Res 66: 8762-8769.

64. Mentzer SJ, Fingeroth J, Reilly JJ, Perrine SP, Faller DV (1998) Arginine butyrate-induced susceptibility to ganciclovir in an Epstein-Barr-virusassociated lymphoma. Blood Cells Mol. Dis 24: 114-123.

65. Wildeman MA, Novalic Z, Verkuijlen SA, Juwana H, Huitema AD, et al. (2012) Cytolytic virus activation therapy for Epstein-Barr virus-driven tumors. Clin Cancer Res 18: 5061-5070.

66. Kenney SC, Mertz JE (2014) Regulation of the latent-lytic switch in EpsteinBarr virus. Semin Cancer Biol 26: 60-68

67. Lee HG, Kim H, Kim EJ, Park PG, Dong SM, et al. (2015) Targeted therapy for Epstein-Barr virus-associated gastric carcinoma using low-dose gemcitabineinduced lytic activation. Oncotarget 6: 31018-31029.

68. Stoker SD, NovaliÄ Z, Wildeman MA, Huitema AD, Verkuijlen SA, et al. (2015) Epstein-Barr virus-targeted therapy in nasopharyngeal carcinoma. $\mathrm{J}$ Cancer Res Clin Oncol 141: 1845-1857.

69. Hutajulu SH, Kurnianda J, Tan IB, Middeldorp JM (2014) Therapeutic implications of Epstein-Barr virus infection for the treatment of nasopharyngeal carcinoma. Ther Clin Risk Manag 10: 721-736.

70. Daskalogianni C, Pyndiah S, Apcher S, Mazars A, Manoury B, et al. (2015) Epstein-Barr virus-encoded EBNA1 and ZEBRA: targets for therapeutic strategies against EBV-carrying cancers. J Pathol 235: 334-341.

71. Shankar S, Srivastava RK (2008) Histone deacetylase inhibitors: mechanisms and clinical significance in cancer: HDAC inhibitor-induced apoptosis. Adv Exp Med Biol 615: 261-298.

72. Bolden JE, Peart MJ, Johnstone RW (2006) Anticancer activities of histone deacetylase inhibitors. Nat Rev Drug Discov 5: 769-784.

73. Marks PA, Xu WS (2009) Histone deacetylase inhibitors: Potential in cancer therapy. J Cell Biochem 107: 600-608.

74. Woellmer A, Hammerschmidt W (2013) Epstein-Barr virus and host cell methylation: regulation of latency, replication and virus reactivation. Curr Opin Virol 3: 260-265

75. Kramer OH, Zhu P, Ostendorff HP, Golebiewski M, Tiefenbach J, et al. (2003) The histone deacetylase inhibitor valproic acid selectively induces proteasomal degradation of HDAC2. EMBO J 22: 3411-3420.

76. Milutinovic S, D'Alessio AC, Detich N, Szyf M (2007) Valproate induces widespread epigenetic reprogramming which involves demethylation of specific genes. Carcinogenesis 28: 560-571.

77. Detich N, Bovenzi V, Szyf M (2003) Valproate induces replication-independent active DNA demethylation. J Biol Chem 278: 27586-27592. 
Citation: Novalić Z, van Rossen TM, Greijer AE, Middeldorp JM (2016) Agents and Approaches for Lytic Induction Therapy of Epstein-Barr Virus Associated Malignancies. Med chem (Los Angeles) 6: 449-466. doi:10.4172/2161-0444.1000384

78. Iwata S, Saito T, Ito Y, Kamakura M, Gotoh K, et al. (2012) Antitumor activities of valproic acid on Epstein-Barr virus-associated T and natural killer lymphoma cells. Cancer Sci 103: 375-381.

79. Countryman JK, Gradoville L, Miller G (2008) Histone hyperacetylation occurs on promoters of lytic cycle regulatory genes in Epstein-Barr virus-infected cell lines which are refractory to disruption of latency by histone deacetylase inhibitors. J. Virol 82: 4706-4719.

80. Marchion DC, Bicaku E, Daud Al, Sullivan DM, Munster PN (2005) Valproic acid alters chromatin structure by regulation of chromatin modulation proteins Cancer Res 65: 3815-3822.

81. Xu WS, Parmigiani RB, Marks PA (2007) Histone deacetylase inhibitors: molecular mechanisms of action. Oncogene 26: 5541-5552.

82. Nebbioso A, Carafa V, Benedetti R, Altucci L (2012) Trials with 'epigenetic' drugs: an update. Mol Oncol 6: 657-682.

83. Seo JS, Cho NY, Kim HR, Tsurumi T, Jang YS, et al. (2008) Cell cycle arrest and lytic induction of EBV-transformed B lymphoblastoid cells by a histone deacetylase inhibitor, Trichostatin A. Oncol Rep 19: 93-98.

84. Hui KF, Chiang AK (2010) Suberoylanilide hydroxamic acid induces viral lytic cycle in Epstein-Barr virus-positive epithelial malignancies and mediates enhanced cell death. Int. J. Cancer 126: 2479-2489.

85. Ye J, Gradoville L, Daigle D, Miller G (2007) De novo protein synthesis is required for lytic cycle reactivation of Epstein-Barr virus, but not Kaposi's sarcoma-associated herpesvirus, in response to histone deacetylase inhibitors and protein kinase C agonists. J. Virol 81: 9279-9291.

86. Jung EJ, Lee YM, Lee BL, Chang MS, Kim WH (2007) Lytic induction and apoptosis of Epstein-Barr virus-associated gastric cancer cell line with epigenetic modifiers and ganciclovir. Cancer Lett 247: 77-83.

87. Li Y, Zhang Y, Fu M, Yao Q, Zhuo H, et al. (2012) Parthenolide induces apoptosis and lytic cytotoxicity in Epstein-Barr virus-positive Burkitt lymphoma. Mol Med Rep 6: 477-482.

88. Nishikawa J, Kis LL, Liu A, Zhang X, Takahara M, et al. (2004) Upregulation of LMP1 expression by histone deacetylase inhibitors in an EBV carrying NPC cell line. Virus Genes 28: 121-128.

89. Marks PA (2007) Discovery and development of SAHA as an anticancer agent. Oncogene 26: 1351-1356.

90. Park JH, Faller DV (2002) Epstein-Barr virus latent membrane protein-1 induction by histone deacetylase inhibitors mediates induction of intercellular adhesion molecule-1 expression and homotypic aggregation. Virology 303: 345-363.

91. Kurokawa M, Ghosh SK, Ramos JC, Mian AM, Toomey NL, et al. (2005) Azidothymidine inhibits NF-kappaB and induces Epstein-Barr virus gene expression in Burkitt lymphoma. Blood 106: 235-240.

92. Hui KF, Ho DN, Tsang CM, Middeldorp JM, Tsao GS, et al. (2012) Activation of lytic cycle of Epstein-Barr virus by suberoylanilide hydroxamic acid leads to apoptosis and tumor growth suppression of nasopharyngeal carcinoma. Int. J. Cancer 131: 1930-1940.

93. Hui KF, Lam BH, Ho DN, Tsao SW, Chiang AK (2013) Bortezomib and SAHA synergistically induce ROS-driven caspase-dependent apoptosis of nasopharyngeal carcinoma and block replication of Epstein-Barr virus. Mol. Cancer Ther 12: 747-758.

94. Hui KF, Leung YY, Yeung PL, Middeldorp JM, Chiang AK (2014) Combination of SAHA and bortezomib up-regulates CDKN2A and CDKN1A and induces apoptosis of Epstein-Barr virus-positive Wp-restricted Burkitt lymphoma and lymphoblastoid cell lines. Br. J. Haematol 167: 639-650.

95. Piekarz RL, Robey R, Sandor V, Bakke S, Wilson WH, et al. (2001) Inhibitor of histone deacetylation, depsipeptide (FR901228), in the treatment of peripheral and cutaneous T-cell lymphoma: a case report. Blood 98: 2865-2868.

96. Whittaker SJ, Demierre MF, Kim EJ, Rook AH, Lerner A, et al. (2010) Final results from a multicenter, international, pivotal study of romidepsin in refractory cutaneous T-cell lymphoma. J. Clin. Oncol 28: 4485-4491.

97. Hui KF, Cheung AK, Choi CK, Yeung PL, Middeldorp JM, et al. (2016) Inhibition of class I histone deacetylases by romidepsin potently induces Epstein-Barr virus lytic cycle and mediates enhanced cell death with ganciclovir. Int. J. Cancer 138: 125-136.

98. Kim SJ, Kim JH, Ki CS, Ko YH, Kim JS (2016) Epstein-Barr virus reactivation in extranodal natural killer/T-cell lymphoma patients: a previously unrecognized serious adverse event in a pilot study with romidepsin. Ann. Oncol 27: 508-513.
99. Anisimová E, Prachová K, Roubal J, Vonka V (1984) Effects of n-butyrate and phorbol ester (TPA) on induction of Epstein-Barr virus antigens and cell differentiation. Arch Virol 81: 223-237.

100. Ghosh SK, Perrine SP, Faller DV (2012) Advances in Virus-Directed Therapeutics against Epstein-Barr Virus-Associated Malignancies. Adv Virol 2012: 509296.

101. zur Hausen H, O'Neill FJ, Freese UK, Hecker E (1978) Persisting oncogenic herpesvirus induced by the tumour promotor TPA. Nature 272: 373-375.

102. Davies AH, Grand RJ, Evans FJ, Rickinson AB (1991) Induction of EpsteinBarr virus lytic cycle by tumor-promoting and non-tumor-promoting phorbol esters requires active protein kinase C. J. Virol 65: 6838-6844.

103. Gao X, Ikuta K, Tajima M, Sairenji T (2001) 12-O-tetradecanoylphorbol-13 acetate induces Epstein-Barr virus reactivation via NF-kappaB and AP-1 as regulated by protein kinase $C$ and mitogen-activated protein kinase. Virology 286: 91-99.

104. Gradoville L, Kwa D, El-Guindy A, Miller G (2002) Protein kinase C-independent activation of the Epstein-Barr virus lytic cycle. J Virol 76 : 5612-5626.

105. Daigle D, Gradoville L, Tuck D, Schulz V, Wang'ondu R, et al. (2011) Valproic acid antagonizes the capacity of other histone deacetylase inhibitors to activate the Epstein-barr virus lytic cycle. J Virol 85: 5628-5643.

106. Mentzer SJ, Perrine SP, Faller DV (2001) Epstein--Barr virus post-transplant lymphoproliferative disease and virus-specific therapy: pharmacological reactivation of viral target genes with arginine butyrate. Transpl. Infect. Dis 3 177-185.

107. Perrine SP Hermine O, Small T, Suarez F, O'Reilly R, et al. (2007) A phase $1 / 2$ trial of arginine butyrate and ganciclovir in patients with Epstein-Barr virus-associated lymphoid malignancies. Blood 109: 2571-2578.

108. Stevens SJ, Zwaan CM, Verkuijlen SA, Middeldorp JM (2006) Epstein-Bar virus (EBV) serology for predicting distant metastases in a white juvenile patient with nasopharyngeal carcinoma and no clinical response to EBV lytic induction therapy. Head Neck 28: 1040-1045.

109. Jones K, Nourse J, Corbett G, Gandhi MK (2010) Sodium valproate in combination with ganciclovir induces lysis of EBV-infected lymphoma cells without impairing EBV-specific T-cell immunity. Int J Lab Hematol 32: e169-174.

110. Ji Jung E, Mie Lee Y, Lan Lee B, Soo Chang M, Ho Kim W (2007) Ganciclovir augments the lytic induction and apoptosis induced by chemotherapeutic agents in an Epstein-Barr virus-infected gastric carcinoma cell line. Anticancer Drugs 18: 79-85.

111. Li L, Su X, Choi GC, Cao Y, Ambinder RF, et al. (2012) Methylation profiling of Epstein-Barr virus immediate-early gene promoters, BZLF1 and BRLF1 in tumors of epithelial, NK- and B-cell origins. BMC Cancer 12: 125.

112. Arvey A, Tempera I, Lieberman PM (2013) Interpreting the Epstein-Barr Virus (EBV) epigenome using high-throughput data. Viruses 5: 1042-1054.

113. Ambinder RF, Robertson KD, Tao Q (1999) DNA methylation and the Epstein-Barr virus. Semin Cancer Biol 9: 369-375.

114. Tsai CL, Li HP, Lu YJ, Hsueh C, Liang Y, et al. (2006) Activation of DNA methyltransferase 1 by EBV LMP1 Involves c-Jun $\mathrm{NH}(2)$-terminal kinase signaling. Cancer Res 66: 11668-11676.

115. Niller HH, Szenthe K, Minarovits J (2014) Epstein-Barr virus-host cell interactions: an epigenetic dialog? Front Genet 5: 367.

116. Babcock GJ, Decker LL, Volk M, Thorley-Lawson DA (1998) EBV persistence in memory B cells in vivo. Immunity 9: 395-404.

117. Arvey A, Tempera I, Tsai K, Chen HS, Tikhmyanova N, et al. (2012) An atlas of the Epstein-Barr virus transcriptome and epigenome reveals host-virus regulatory interactions. Cell Host Microbe 12: 233-245.

118. Hutajulu SH, Indrasari SR, Indrawati LP, Harijadi A, Duin S, et al. (2011) Epigenetic markers for early detection of nasopharyngeal carcinoma in a high risk population. Mol Cancer 10: 48.

119. Hattori N, Ushijima T (2016) Epigenetic impact of infection on carcinogenesis mechanisms and applications. Genome Med 8: 10.

120. Nonkwelo CB, Long WK (1993) Regulation of Epstein-Barr virus BamHI-H divergent promoter by DNA methylation. Virology 197: 205-215.

121. Ben-Sasson SA, Klein G (1981) Activation of the Epstein-Barr virus genome by 5 -aza-cytidine in latently infected human lymphoid lines. Int $\mathrm{J}$ Cancer 28 : 131-135. 
Citation: Novalić Z, van Rossen TM, Greijer AE, Middeldorp JM (2016) Agents and Approaches for Lytic Induction Therapy of Epstein-Barr Virus Associated Malignancies. Med chem (Los Angeles) 6: 449-466. doi:10.4172/2161-0444.1000384

122. Moore SM, Cannon JS, Tanhehco YC, Hamzeh FM, Ambinder RF (2001) Induction of Epstein-Barr virus kinases to sensitize tumor cells to nucleoside analogues. Antimicrob Agents Chemother 45: 2082-2091.

123. Hagemeier SR, Barlow EA, Meng Q, Kenney SC (2012) The cellular ataxia telangiectasia-mutated kinase promotes epstein-barr virus lytic reactivation in response to multiple different types of lytic reactivation-inducing stimuli. J. Virol 86: 13360-13370.

124. Dos Santos Ferreira AC, Fernandes RA, Kwee JK, Klumb CE (2012) Histone deacetylase inhibitor potentiates chemotherapy-induced apoptosis through Bim upregulation in Burkitt's lymphoma cells. J. Cancer Res. Clin. Oncol 138: 317-325.

125. Richter-Larrea JA, Robles EF, Fresquet V, Beltran E, Rullan AJ, et al. (2010) Reversion of epigenetically mediated BIM silencing overcomes chemoresistance in Burkitt lymphoma. Blood 116: 2531-2542.

126. Feng WH, Israel B, Raab-Traub N, Busson P, Kenney SC (2002) Chemotherapy induces lytic EBV replication and confers ganciclovir susceptibility to EBV-positive epithelial cell tumors. Cancer Res 62: 19201926.

127. Wijdeven RH, Pang B, van der Zanden SY, Qiao X, Blomen V, et al. (2015) Genome-Wide Identification and Characterization of Novel Factors Conferring Resistance to Topoisomerase II Poisons in Cancer. Cancer Res 75: 4176-4187.

128. Pang B, Qiao X, Janssen L, Velds A, Groothuis T, et al. (2013) Drug-induced histone eviction from open chromatin contributes to the chemotherapeutic effects of doxorubicin. Nat Commun 4: 1908

129. Shin HJ, Kim do N, Lee SK (2011) Association between Epstein-Barr virus infection and chemoresistance to docetaxel in gastric carcinoma. Mol Cells 32: 173-179.

130. Miller WH Jr, Schipper HM, Lee JS, Singer J, Waxman S (2002) Mechanisms of action of arsenic trioxide. Cancer Res 62: 3893-3903.

131. Sides MD, Block GJ, Shan B, Esteves KC, Lin Z, et al. (2011) Arsenic mediated disruption of promyelocytic leukemia protein nuclear bodies induces ganciclovir susceptibility in Epstein-Barr positive epithelial cells. Virology 416: 86-97.

132. Wagner JM, Hackanson B, Lübbert M, Jung M (2010) Histone deacetylase (HDAC) inhibitors in recent clinical trials for cancer therapy. Clin Epigenetics 1: $117-136$.

133. West AC, Johnstone RW (2014) New and emerging HDAC inhibitors for cancer treatment. J Clin Invest 124: 30-39.

134. Shyamasundar S, Dheen ST, Bay BH (2016) Histone Modifications as Molecular Targets in Nasopharyngeal Cancer. Curr Med Chem 23: 186-197.

135. Tikhmyanova N, Schultz DC, Lee T, Salvino JM, Lieberman PM (2014) Identification of a new class of small molecules that efficiently reactivate latent Epstein-Barr Virus. ACS Chem Biol 9: 785-795.

136. Choi CK, Ho DN, Hui KF, Kao RY, Chiang AK (2015) Identification of Nove Small Organic Compounds with Diverse Structures for the Induction of Epstein-Barr Virus (EBV) Lytic Cycle in EBV-Positive Epithelial Malignancies. PLoS. One 10: e0145994.

137. Lassoued S, Gargouri B, El Feki Ael F, Attia H, Van Pelt J (2010) Transcription of the Epstein-Barr virus lytic cycle activator BZLF-1 during oxidative stress induction. Biol Trace Elem Res 137: 13-22.

138. Huang SY, Fang CY, Wu CC, Tsai CH, Lin SF, et al. (2013) Reactive oxygen species mediate Epstein-Barr virus reactivation by $\mathrm{N}$-methyl-N'-nitro-Nnitrosoguanidine. PLoS One 8: e84919.

139. Li R, Zhu J, Xie Z, Liao G, Liu J, et al. (2011) Conserved herpesvirus kinases target the DNA damage response pathway and TIP60 histone acetyltransferase to promote virus replication. Cell Host. Microbe 10: 390400 .

140. Inoue H, Mishima K, Yamamoto-Yoshida S, Ushikoshi-Nakayama R, Nakagawa $Y$, et al. (2012) Aryl hydrocarbon receptor-mediated induction of EBV reactivation as a risk factor for Sjogren's syndrome. J. Immunol 188: 4654-4662.

141. Mannick JB, Asano K, Izumi K, Kieff E, Stamler JS (1994) Nitric oxide produced by human $B$ lymphocytes inhibits apoptosis and Epstein-Barr virus reactivation. Cell 79: 1137-1146.

142. Gao X, Tajima M, Sairenji T (1999) Nitric oxide down-regulates Epstein-Barr virus reactivation in epithelial cell lines. Virology 258: 375-381.
143. Prince S, Keating S, Fielding C, Brennan P, Floettmann E, et al. (2003) Latent membrane protein 1 inhibits Epstein-Barr virus lytic cycle induction and progress via different mechanisms. J Virol 77: 5000-5007.

144. Huen DS, Henderson SA, Croom-Carter D, Rowe M (1995) The Epstein-Barr virus latent membrane protein-1 (LMP1) mediates activation of NF-kappa B and cell surface phenotype via two effector regions in its carboxy-terminal cytoplasmic domain. Oncogene 10: 549-560.

145. Yin L, Liao W, Deng X, Tang M, Gu H, et al. (2001) LMP1 activates NF-kappa $B$ via degradation of I kappa $B$ alpha in nasopharyngeal carcinoma cells. Chin Med J (Engl) 114: 718-722.

146. Liu SF, Wang H, Lin XC, Xiang H, Deng XY, et al. (2008) NF-kappaB inhibitors induce lytic cytotoxicity in Epstein-Barr virus-positive nasopharyngeal carcinoma cells. Cell Biol Int 32: 1006-1013.

147. Cuesta E, Boada J, Perales JC, Roig T, Bermudez J (2005) Aspirin inhibits NF-kappaB activation in a glycolysis-depleted lung epithelial cell line. Eur J Pharmacol 517: 158-164.

148. Liu SF, Wang H, Li ZJ, Deng XY, Xiang H, et al. (2008) Aspirin induces lytic cytotoxicity in Epstein-Barr virus-positive cells. Eur. J. Pharmacol 589: 8-13.

149. Pareek A, Suthar M, Rathore GS, Bansal V (2011) Feverfew (Tanacetum parthenium L.): A systematic review. Pharmacogn Rev 5: 103-110.

150. Dai Y, Guzman ML, Chen S, Wang L, Yeung SK, et al. (2010) The NF (Nuclear factor)-kappaB inhibitor parthenolide interacts with histone deacetylase inhibitors to induce MKK7/JNK1-dependent apoptosis in human acute myeloid leukaemia cells. Br. J. Haematol 151: 70-83.

151. Faggioni A, Zompetta C, Grimaldi S, Barile G, Frati L, et al. (1986) Calcium modulation activates Epstein-Barr virus genome in latently infected cells. Science 232: 1554-1556.

152. Murata T, Noda C, Saito S, Kawashima D, Sugimoto A, et al. (2011) Involvement of Jun dimerization protein 2 (JDP2) in the maintenance of Epstein-Barr virus latency. J Biol Chem 286: 22007-22016.

153. Bayraktar UD, Diaz LA, Ashlock B, Toomey N, Cabral L, et al. (2014) Zidovudine-based lytic-inducing chemotherapy for Epstein-Barr virus-related lymphomas. Leuk Lymphoma 55: 786-794.

154. Pan YR, Fang CY, Chang YS, Chang HY (2005) Analysis of Epstein-Barr virus gene expression upon phorbol ester and hydroxyurea treatment by realtime quantitative PCR. Arch Virol 150: 755-770.

155. Liu YR, Huang SY, Chen JY, Wang LH (2013) Microtubule depolymerization activates the Epstein-Barr virus lytic cycle through protein kinase $C$ pathways in nasopharyngeal carcinoma cells. J. Gen. Virol 94: 2750-2758.

156. Yang EV, Webster Marketon JI, Chen M, Lo KW, Kim SJ, et al. (2010) Glucocorticoids activate Epstein Barr virus lytic replication through the upregulation of immediate early BZLF1 gene expression. Brain Behav. Immun 24: 1089-1096.

157. Godbout JP, Glaser R (2006) Stress-induced immune dysregulation: implications for wound healing, infectious disease and cancer. J. Neuroimmune. Pharmacol 1: 421-427.

158. Daibata M, Bandobashi K, Kuroda M, Imai S, Miyoshi I, et al. (2005) Induction of lytic Epstein-Barr virus (EBV) infection by synergistic action of rituximab and dexamethasone renders EBV-positive lymphoma cells more susceptible to ganciclovir cytotoxicity in vitro and in vivo. J. Virol 79: 5875-5879.

159. Wu T, Wang S, Wu J, Lin Z, Sui X, et al. (2015) Icaritin induces lytic cytotoxicity in extranodal NK/T-cell lymphoma. J Exp Clin Cancer Res 34: 17

160. Lieberman PM (2015) Chromatin Structure of Epstein-Barr Virus Latent Episomes. Curr Top Microbiol Immunol 390: 71-102.

161. Hammerschmidt W (2015) The Epigenetic Life Cycle of Epstein-Barr Virus. Curr Top Microbiol Immunol 390: 103-117.

162. Jung YJ, Choi H, Kim H, Lee SK (2014) MicroRNA miR-BART20-5p stabilizes Epstein-Barr virus latency by directly targeting BZLF1 and BRLF1. J Virol 88 9027-9037.

163. Lin X, Tsai MH, Shumilov A, et al. (2015) The Epstein-Barr Virus BART miRNA Cluster of the M81 Strain Modulates Multiple Functions in Primary B Cells. PLoS Pathog 11: e1005344.

164. Vento-Tormo R, Rodríguez-Ubreva J, Lisio LD, Islam AB, Urquiza JM, et al. (2014) NF-kappaB directly mediates epigenetic deregulation of common microRNAs in Epstein-Barr virus-mediated transformation of B-cells and in lymphomas. Nucleic Acids Res 42: 11025-11039. 
Citation: Novalić Z, van Rossen TM, Greijer AE, Middeldorp JM (2016) Agents and Approaches for Lytic Induction Therapy of Epstein-Barr Virus Associated Malignancies. Med chem (Los Angeles) 6: 449-466. doi:10.4172/2161-0444.1000384

165. Verhoeven RJ, Tong S, Zhang G, Zong J, Chen Y, et al. (2016) NF-îo B Signaling Regulates Expression of Epstein-Barr Virus BART MicroRNAs and Long Noncoding RNAs in Nasopharyngeal Carcinoma. J Virol 90: 6475-6488.

166. Gewurz BE, Mar JC, Padi M, Zhao B, Shinners NP, et al. (2011) Canonical NF-kappaB activation is essential for Epstein-Barr virus latent membrane protein 1 TES2/CTAR2 gene regulation. J Virol 85: 6764-6773.

167. Zheng H, Li LL, Hu DS, Deng XY, Cao Y (2007) Role of Epstein-Barr virus encoded latent membrane protein 1 in the carcinogenesis of nasopharyngeal carcinoma. Cell Mol Immunol 4: 185-196.

168. Hill ER, Koganti S, Zhi J, Megyola C, Freeman AF, et al. (2013) Signal transducer and activator of transcription 3 limits Epstein-Barr virus lytic activation in B lymphocytes. J Virol 87: 11438-11446.

169. Chen H, Hutt-Fletcher L, Cao L, Hayward SD (2003) A positive autoregulatory loop of LMP1 expression and STAT activation in epithelial cells latently infected with Epstein-Barr virus. J Virol 77: 4139-4148.

170. Liu S, Liu P, Borras A, Chatila T, Speck SH (1997) Cyclosporin A-sensitive induction of the Epstein-Barr virus lytic switch is mediated via a novel pathway involving a MEF2 family member. EMBO J 16: 143-153.

171. Speck SH, Chatila T, Flemington E (1997) Reactivation of Epstein-Barr virus: regulation and function of the BZLF1 gene. Trends Microbiol 5: 399-405.

172. Miska EA, Karlsson C, Langley E, Nielsen SJ, Pines J, et al. (1999) HDAC4 deacetylase associates with and represses the MEF2 transcription factor. EMBO J 18: 5099-5107.

173. Lu J, McKinsey TA, Nicol RL, Olson EN (2000) Signal-dependent activation of the MEF2 transcription factor by dissociation from histone deacetylases. Proc Natl Acad Sci USA 97: 4070-4075.

174. Lu J, Chen SY, Chua HH, Liu YS, Huang YT, et al. (2000) Upregulation of tyrosine kinase TKT by the Epstein-Barr virus transactivator Zta. J. Virol 74: 7391-7399.

175. Gruffat $H$, Manet E, Sergeant A (2002) MEF2-mediated recruitment of class II HDAC at the EBV immediate early gene BZLF1 links latency and chromatin remodeling. EMBO Rep 3: 141-146.

176. Heather J, Flower K, Isaac S, Sinclair AJ (2009) The Epstein-Barr virus lytic cycle activator Zta interacts with methylated ZRE in the promoter of host target gene egr1. J Gen Virol 90: 1450-1454.

177. Fenton M, Sinclair AJ (1999) Divergent requirements for the MAPK (ERK) signal transduction pathway during initial virus infection of quiescent primary $\mathrm{B}$ cells and disruption of Epstein-Barr virus latency by phorbol esters. J. Virol 73: 8913-8916.

178. Yuan PX, Huang LD, Jiang YM, Gutkind JS, Manji HK, et al. (2001) The mood stabilizer valproic acid activates mitogen-activated protein kinases and promotes neurite growth. J. Biol. Chem 276: 31674-31683.

179. Ferreira AC, Robaina MC, Rezende LM, Severino P, Klumb CE (2014) Histone deacetylase inhibitor prevents cell growth in Burkitt's lymphoma by regulating $\mathrm{PI} 3 \mathrm{~K} / \mathrm{Akt}$ pathways and leads to upregulation of miR-143, miR145, and miR-101. Ann Hematol 93: 983-993.

180. Murata T, Narita Y, Sugimoto A, Kawashima D, Kanda T, et al. (2013) Contribution of myocyte enhancer factor 2 family transcription factors to BZLF1 expression in Epstein-Barr virus reactivation from latency. J Virol 87: 10148-10162.

181. Davie JR (2003) Inhibition of histone deacetylase activity by butyrate. J Nutr 133: 2485S-2493S

182. Huang J, Liao G, Chen H, Wu FY, Hutt-Fletcher L, et al. (2006) Contribution of C/EBP proteins to Epstein-Barr virus lytic gene expression and replication in epithelial cells. J Virol 80: 1098-1109.

183. Kraus RJ, Perrigoue JG, Mertz JE (2003) ZEB negatively regulates the lyticswitch BZLF1 gene promoter of Epstein-Barr virus. J Virol 77: 199-207.

184. Yu X, Wang Z, Mertz JE (2007) ZEB1 regulates the latent-lytic switch in infection by Epstein-Barr virus. PLoS Pathog 3: e194

185. Ellis AL, Wang Z, Yu X, Mertz JE (2010) Either ZEB1 or ZEB2/SIP1 can play a central role in regulating the Epstein-Barr virus latent-lytic switch in a celltype-specific manner. J Virol 84: 6139-6152.

186. Ellis-Connell AL, lempridee T, Xu I, Mertz JE (2010) Cellular microRNAs $200 \mathrm{~b}$ and 429 regulate the Epstein-Barr virus switch between latency and lytic replication. J Virol 84: 10329-10343.
187. Feng W, Kraus RJ, Dickerson SJ, Lim HJ, Jones RJ, et al. (2007) ZEB1 and C-Jun levels contribute to the establishment of highly lytic Epstein-Barr virus infection in gastric AGS cells. J Virol 81: 10113-10122.

188. Zhao J, Jin H, Cheung KF, Tong JH, Zhang S, et al. (2012) Zinc finger E-box binding factor 1 plays a central role in regulating Epstein-Barr virus (EBV) latent-lytic switch and acts as a therapeutic target in EBV-associated gastric cancer. Cancer 118: 924-936.

189. Daibata M, Speck SH, Mulder C, Sairenji T (1994) Regulation of the BZLF1 promoter of Epstein-Barr virus by second messengers in anti-immunoglobulintreated B cells. Virology 198: 446-454.

190. Lee HH, Chang SS, Lin SJ, Chua HH, Tsai TJ, et al. (2008) Essential role of PKCdelta in histone deacetylase inhibitor-induced Epstein-Barr virus reactivation in nasopharyngeal carcinoma cells. J. Gen. Virol 89: 878-883.

191. Chang LK, Lee YH, Cheng TS, Hong YR, Lu PJ, et al. (2004) Posttranslational modification of Rta of Epstein-Barr virus by SUMO-1. J Bio Chem 279: 38803-38812.

192. Chang LK, Chung JY, Hong YR, Ichimura T, Nakao M, et al. (2005) Activation of Sp1-mediated transcription by Rta of Epstein-Barr virus via an interaction with MCAF1. Nucleic Acids Res 33: 6528-6539.

193. Gonnella R, Granato M, Farina A, Santarelli R, Faggioni A, et al. (2015) PKC theta and p38 MAPK activate the EBV lytic cycle through autophagy induction. Biochim Biophys Acta 1853: 1586-1595.

194. Kudoh A, Fujita M, Zhang L, Shirata N, Daikoku T, et al. (2005) EpsteinBarr virus lytic replication elicits ATM checkpoint signal transduction while providing an S-phase-like cellular environment. J. Biol. Chem 280: 8156-8163.

195. Kudoh A, Iwahori S, Sato Y, Nakayama S, Isomura H, et al. (2009) Homologous recombinational repair factors are recruited and loaded onto the viral DNA genome in Epstein-Barr virus replication compartments. J. Virol 83: 6641-6651.

196. Schmaus S, Wolf $H$, Schwarzmann $F(2004)$ The reading frame BPLF1 of Epstein-Barr virus: a homologue of herpes simplex virus protein VP16. Virus Genes 29: 267-277.

197. Gastaldello S, Hildebrand S, Faridani O, Callegari S, Palmkvist M, et al (2010) A deneddylase encoded by Epstein-Barr virus promotes viral DNA replication by regulating the activity of cullin-RING ligases. Nat Cell Biol 12: 351-361.

198. Mauser A, Saito S, Appella E, Anderson CW, Seaman WT, et al. (2002) The Epstein-Barr virus immediate-early protein BZLF1 regulates p53 function through multiple mechanisms. J Virol 76: 12503-12512.

199. Bailey SG, Verrall E, Schelcher C, Rhie A, Doherty AJ, et al. (2009) Functional interaction between Epstein-Barr virus replication protein Zta and host DNA damage response protein 53BP1. J. Virol 83: 11116-11122.

200. Wang'ondu R, Teal S, Park R, Heston L, Delecluse H, et al. (2015) DNA Damage Signaling Is Induced in the Absence of Epstein-Barr Virus (EBV) Lytic DNA Replication and in Response to Expression of ZEBRA. PLoS One 10: e0126088

201. Bell P, Lieberman PM, Maul GG (2000) Lytic but not latent replication of epstein-barr virus is associated with PML and induces sequential release of nuclear domain 10 proteins. J Virol 74: 11800-11810.

202. Adamson AL, Kenney S (2001) Epstein-barr virus immediate-early protein BZLF1 is SUMO-1 modified and disrupts promyelocytic leukemia bodies. J Virol 75: 2388-2399.

203. Countryman J, Jenson H, Seibl R, Wolf H, Miller G (1987) Polymorphic proteins encoded within BZLF1 of defective and standard Epstein-Barr viruses disrupt latency. J Virol 61: 3672-3679.

204. Nikitin PA, Yan CM, Forte E, Bocedi A, Tourigny JP, et al. (2010) An ATM Chk2-mediated DNA damage-responsive signaling pathway suppresses Epstein-Barr virus transformation of primary human B cells. Cell Host. Microbe 8: 510-522.

205. Guo Z, Deshpande R, Paull TT (2010) ATM activation in the presence of oxidative stress. Cell Cycle 9: 4805-4811.

206. Chang SS, Lo YC, Chua HH, Chiu HY, Tsai SC, et al. (2008) Critical role of p53 in histone deacetylase inhibitor-induced Epstein-Barr virus Zta expression. J Virol 82: 7745-7751. 
Citation: Novalić Z, van Rossen TM, Greijer AE, Middeldorp JM (2016) Agents and Approaches for Lytic Induction Therapy of Epstein-Barr Virus Associated Malignancies. Med chem (Los Angeles) 6: 449-466. doi:10.4172/2161-0444.1000384

207. Chua HH, Chiu HY, Lin SJ, Weng PL, Lin JH, et al. (2012) p53 and Sp1 cooperate to regulate the expression of Epstein-Barr viral Zta protein. J Med Virol 84: 1279-1288.

208. Hau PM, Deng W, Jia L, Yang J, Tsurumi T, et al. (2015) Role of ATM in the formation of the replication compartment during lytic replication of EpsteinBarr virus in nasopharyngeal epithelial cells. J Virol 89: 652-668.

209. Sato Y, Tsurumi T (2013) Genome guardian p53 and viral infections. Rev Med Virol 23: 213-220.

210. Gruhne B, Sompallae R, Masucci MG (2009) Three Epstein-Barr virus latency proteins independently promote genomic instability by inducing DNA damage, inhibiting DNA repair and inactivating cell cycle checkpoints. Oncogene 28: 3997-4008.
211. Cai Q, Guo Y, Xiao B, Banerjee S, Saha A, et al. (2011) Epstein-Barr virus nuclear antigen $3 \mathrm{C}$ stabilizes Gemin3 to block p53-mediated apoptosis. PLoS Pathog 7: e1002418.

212. Matsuoka S, Ballif BA, Smogorzewska A, McDonald ER 3rd, Hurov KE, et al. (2007) ATM and ATR substrate analysis reveals extensive protein networks responsive to DNA damage. Science 316: 1160-1166.

213. Chen D, Shen A, Fang G, Liu H, Zhang M, et al. (2016) Tetrahydroisoquinolines as novel histone deacetylase inhibitors for treatment of cancer. Acta Pharm Sin B 6: 93-99.

214. Fontana E, Smyth EC (2016) Novel targets in the treatment of advanced gastric cancer: a perspective review. Ther Adv Med Oncol 8: 113-125. 